Proc. Estonian Acad. Sci. Geol., 1998, 47, 3, 173-194

\title{
TRILOBITES OF THE GENUS TOXOCHASMOPS FROM THE ORDOVICIAN OF ESTONIA
}

\author{
Arvo RÕÕMUSOKS
}

Institute of Geology, University of Tartu, Vanemuise 46, EE-2400 Tartu, Estonia; e-mail: geol@ut.ee

Received 2 March 1998, in revised form 27 March 1998

Abstract. A study of the genus Toxochasmops from northern Estonia revealed that it is more diverse both at the generic and specific levels than was known previously. The earliest species of Toxochasmops from the upper Viru Series were assigned to the new subgenus T. (Schmidtops). Apart from the type species Phacops (Chasmops) maxima Schmidt, 1881, this subgenus comprises the new species $T$. (S.) proavus and $T$. (S.) vironiensis.

The subgenus T. (Toxochasmops) includes Chasmops inge Rõomusoks, 1953, P. (C.) wesenbergensis Schmidt, 1881, as well as the new species $T$. (T.) estonicus, $T$. (T.) notabilis, and $T$. (T.) vormsiensis. The earliest representative of this subgenus is $T$. (T.) granuliferus sp. nov. from the uppermost Keila Stage of the Viru Series (lower Dicranograptus clingani Zone).

Key words: trilobite, Toxochasmops, Ordovician, Estonia.

The genus Toxochasmops was erected by McNamara (1979) as a group containing, in the first place, the British Upper Ordovician species Phacops (Chasmops) amphora Salter, 1864 from South Wales, P. (C.) marri Reed, 1894 from North England, and P. (C.) bisseti Reed, 1906 from Scotland. Chasmops salopiensis Dean, 1961 from South Shropshire has not been recorded as a Toxochasmops by McNamara although this species is, in Dean's opinion, probably most closely related to $C$. extensus - the type species of the genus. In addition to the above-named British species and Trilobites extensus Boeck, 1838 from Norway, McNamara assigned to this genus also two species from northern Estonia - P. (C.) wesenbergensis Schmidt, 1881 and $P$. (C.) eichwaldi Schmidt, 1881. Phacops macroura Angelin, 1851 from Sweden as well as $P$. (C.) maxima Schmidt, 1881 and $C$. inge Rõõmusoks, 1953 from Estonia were at first not included in this genus. Later McNamara (1980a) placed them all in synonymy with Toxochasmops extensus. Nevertheless, already Schmidt (1881), erecting $P$. (C.) maxima from the Jõhvi and Keila stages of northern Estonia, compared it with the both earlier described Scandinavian species $-P$. macroura and $P$. extensa. 
In doing so he had some Swedish specimens from the erratic boulders of Öland Island, which he believed to represent macroura, and some Norwegian ones from the P. extensa-group (sent to him by Prof. W. C. Brögger) for comparison. Unfortunately, the Scandinavian specimens figured by Schmidt (1881, pl. III, fig. 10; pl. IV, figs. 3, 9; pl. X, fig. 19) as $P$. (C.) maxima are presumably lost (Bruton et al., 1997). According to Schmidt, $P$. (C.) macroura is most similar to $P$. (C.) maxima although somewhat smaller. P. extensa also resembles maxima, but has distinct tubercles on glabella and less developed genal spines. Thus Schmidt assumed that three more or less related but different species of Chasmops occur in the middle Ordovician of Baltoscandia. Warburg (1925) was the first to place $C$. maximus in synonymy with $C$. macrourus although she had not seen the topotype specimens of the former species. Later Haller (1973) has argued likewise and has drawn a strange conclusion that maxima is only an adult development phase of macroura. Actually, maximus occurs in older deposits than macrourus. Besides, according to Haller $C$. extensus is synonymous with $C$. macrourus. The specimens figured by Haller (1973, pl. XI, fig. 2; pl. XII, fig. 2) as C. macrourus have mostly been collected probably from the Macrourus Limestone (= Moldå Topoformation) from erratic boulders in northern Germany and most likely belong to some new species.

Afterwards McNamara (1980a) included also the species Chasmops anticostiensis Twenhofel, 1928 from the Richmondian and Gamachian of Canada and Phacops (Chasmops) mutica Schmidt, 1881 from the Jõhvi and Keila stages of northern Estonia to Toxochasmops. However, $P$. (C.) mutica was later proposed by Rõõmusoks (1986) as the type species of a new genus Oculichasmops which occurs also in Skagen and Kullsberg Limestones in Dalarna, Sweden.

There are yet several problems related to the taxonomy of Norwegian forms of Toxochasmops. For instance, how many species or subspecies there actually occur - either three different but related forms, as stated by Störmer (1980) or only one, as suggested by Owen (Owen \& Harper, 1982; Harper \& Owen, 1984). The present knowledge about the Swedish representatives of Toxochasmops is analogical, in particular, concerning the status of the species T.macrourus (Angelin) which is not yet clear. As long as the specimen figured by Angelin (1851, pl. VII, figs. 3, 4) cannot be found in the collections from Gräsgård Siltstone erratics of Öland Island housed in Swedish museums and there are no other Angelin's syntypes, the assignment of a lectotype is impossible. Consequently this species is not yet valid (V. Jaanusson, pers. comm., 1996).

The present author, together with V. Jaanusson, recently examined the Chasmopinae from Gräsgård Siltstone erratics of Öland Island in the Swedish Museum of Natural History, Stockholm. We found there at least three different species which all, in Warburg's (1925) opinion, constitute a single, although variable species Chasmops macrourus: (1) A relatively small but the most abundant new species with comparatively large eyes which is surely similar to Toxochasmops inge (Rõõmusoks) (this paper Pl. III, fig. 11) but not to maximus. 
Namely this species was figured by Schmidt (1881, pl. III, fig. 10), referred to Phacops (Chasmops) macroura, and compared with $P$. (C.) maxima. (2) Rare, sometimes fairly large forms, maximum width across the genal spines according to Warburg approximately $60 \mathrm{~mm}$, with broad, relatively low glabella covered by evenly fine granules but lacking tubercles (Pl. V, fig. 2; Pl. VIII, fig. 15 in this paper). This is the form, apparently somewhat inadequately, figured by Schmidt (1881, pl. IV, fig. 3) as $P$. (C.) maxima. It may represent a new species of T. (Schmidtops). Unfortunately, Warburg (1925) has not figured any cephalons and pygidia of $C$. macrourus from the erratics of Öland. The large pygidium she figured (pl. XI, figs. 22-24), which has been found from the Lower Leptaena Limestone (now Kullsberg Limestone or Moldå Topoformation) of Dalarna, may be conspecific with a specimen together with a cephalon, found later by V. Jaanusson also from the Kullsberg Limestone (see Pl. VI, fig. 6 here), and probably belongs to a new species of $T$. (Toxochasmops). (3) A small, very rare form with finely tuberculated glabella and elongated narrow sharply triangular pygidium. The glabella is similar to that briefly described and figured by Angelin as $P$. macroura (1851, pl. VII, figs. 3, 4; however, the pygidium in fig. 3 may belong to another species). A figure of glabella with pygidium, probably of this species, was published by McNamara \& Rudkin (1984, fig. 3A) and referred to Toxochasmops extensus. This small specimen (PIU ar 15555) and a specimen (RM Ar 23577), figured here for comparison with Toxochasmops (Schmidtops) maximus (see Pl. II, figs. 11-13; Pl. VI, fig. 5), most likely represent the true $T$. (T.) macrourus in Angelin's interpretation.

In an earlier study, Rõõmusoks (1953) examined the material of Chasmopsspecies from the Oandu Stage (= previous Vasalemma Stage), Hirmuse Formation in northern Estonia, and found there a form which is possibly conspecific with Phacops macroura, as figured by Angelin (1851), Schmidt (1881), Pompecki (1890), and in greater detail described by Warburg (1925). A recent comparison of this Estonian form with Toxochasmops-species from Sweden, mentioned above, suggests that it represents a new species described here as $T$. (T.) estonicus sp. nov.

A form from the Lower Caradoc sandstone of the Chergyn Stage on the western slope of the southern Ural Mountains, described by Antsygin (1970) as Chasmops aff. maxima Schmidt, probably does not belong to Toxochasmops because of the reduction of the L2 glabellar lobe, and a very different pygidial morphology.

Thus, the specific composition of the genus Toxochasmops is not yet established and therefore the main aim of the present paper is to revise the Estonian material assigned to the genus Toxochasmops. The species occurring mainly in the upper Viru Series of Estonia are assigned to the subgenus $T$. (Toxochasmops) and the earliest species of Toxochasmops from the middle Viru Series are included to a new subgenus $T$. (Schmidtops). A study of some species related to Phacops (Chasmops) eichwaldi Schmidt, 1881 from the Harju 
Series of Estonia, representing a separate new genus, remains outside the scope of this paper. These new last mentioned taxa have recently been considered as Chasmops maximus and Chasmops eichwaldi species-groups, respectively (Rõõmusoks, 1997). The latter group includes the species with relatively narrow rachis, flat glabella which lacks L2 and any tuberculation. From the above we may conclude that the diagnosis for the genus Toxochasmops presented by McNamara $(1979,1980 a)$ requires revision. For that reason an emended diagnosis for the genus Toxochasmops is not given here.

According to McNamara (1980b) the chasmopine species evolved during the Viru and Harju epochs in the eastern Baltic region. The importance of the eastern Baltic area as a distribution centre of the genera of the subfamily Pterygometopinae was underlined by Jaanusson \& Ramsköld (1993) who stated that these genera evolved mostly during the Viru and Harju epochs. The appearance of the earliest known genera and species of the subfamily Chasmopinae in the Haljala, Keila, and Oandu stages of the East Baltic, with their later migration to other areas, seems to support this conclusion. The phylogenetic analysis of chasmopines carried out by Haller (1973) and McNamara (1980a) apparently needs revision.

Location of the main exposures mentioned in the text can be found on the maps in Raukas \& Teedumäe (1997). The letters before the catalogue numbers denote the repositories in the following museums: $\mathrm{TUG}=$ Tartu University Geological Museum; RM = Naturhistoriska Riksmuseet, Sektionen för paleozoologi, Stockholm; PIU = Palaeontological Institute, Uppsala University.

Family PTERYGOMETOPIDAE REED, 1905

Subfamily CHASMOPINAE PILLET, 1954

Genus Toxochasmops McNamara, 1979

Type species. Trilobites extensus Boeck, 1838 from the Upper Chasmops Shale and Limestone (= Norderhov and Solvang formations, upper Caradoc Dicranograptus clingani Zone) of Oslo region, Norway; redescribed by Störmer (1940, pp. 138-139; pl. 3, figs. 7-11).

\section{Subgenus Toxochasmops (Toxochasmops) McNamara, 1979}

Type species. As for genus.

Other species. Phacops macroura Sjögren in Angelin, 1851 from the Gräsgård Siltstone boulders on Öland Island, Sweden; Phacops (Chasmops) amphora Salter, 1853 from the lower Ashgillian Grug Limestone of South Wales; P. (C.) wesenbergensis Schmidt, 1881 from the Rakvere Stage of northern Estonia; $P$. (C.) marri Reed, 1894 from the Cautleyan Stage of southern Lake District and 
Wales; P. (C.) bisseti Reed, 1906 from the Ashgillian Drummuck Group of Girvan, Scotland; Chasmops wesenbergensis var. applanata Wiman, 1906 from the Östersjö Limestone erratic boulders in Uppland, Sweden, derived from the submarine South Bothnian area corresponding stratigraphically to the interval from the Rakvere to Pirgu stages of northern Estonia (see Jaanusson, 1958); C. anticostiensis Twenhofel, 1928 from the English Head, Vaureal, and Ellis Bay formations of Anticosti Island, Canada; $C$. inge Rõõmusoks, 1953 from the Oandu Stage of northern Estonia; C. salopiensis Dean, 1961 from the topmost part of the Actonian Stage of South Shropshire; C. extensa (Boeck), sensu Dean (1961), from the Upper Longwillian to the lowest zone of the Onnian Stage of South Shropshire; Toxochasmops (Toxochasmops) granuliferus sp. nov; T. (T.) notabilis sp. nov.; T. (T.) estonicus sp. nov.; $T$. (T.) vormsiensis sp. nov. (the last four new species are described below).

Diagnosis. Cephalon moderately broad with steeply sloping sides. Cephalic border almost horizontal in anterior view. Dorsal furrows nearly straight. Genal spines long and low, lowering already in anterior part. Eyes short, cone-shaped, highly elevated, and positioned usually near glabella. L2 developed as a small knob. Surface of palpebral lobe usually above the level of glabella. Surface sculpture of glabella consists of fine granules, composite tubercles and, rarely, pit-tubercles. Cephalic doublure relatively narrow and evenly gently convex. Pygidium long, normally elongate triangular, more or less flat and with comparatively narrow rachis. Outer portion of pleural areas flatly sloping. Hypostoma with short posterior border.

Occurrence. Except for Toxochasmops (Toxochasmops) anticostiensis from eastern Canada, all the other species of this subgenus occur in Europe, particularly in northern Estonia. They have been identified in Great Britain (South Shropshire, South Wales, Lake District, Girvan), Norway (Oslo area and adjacent districts), Sweden (Siljan district; erratic boulders in Uppland and Öland Island derived from the South Bothnian submarine area), evidently in Poland (Modlinski, 1973), in the Baltic States and Ingria (environs of St Petersburg in NW Russia). The earliest species appeared nearly simultaneously everywhere. Stratigraphically the subgenus $T$. (Toxochasmops) ranges from the lower Dicranograptus clingani Zone (Keila Stage) to the upper Dicellograptus anceps Zone (Pirgu Stage).

\section{Toxochasmops (Toxochasmops) granuliferus sp. nov.}

$$
\text { Plate I, figures 1-4; Plate V, figure } 3
$$

Derivation of name. Latin, granulum + fero, referring to the coarse-grained tuberculation of glabella.

Holotype. Partially preserved cephalon (TUG 991-4) from the Keila Stage, Laagri Substage, Saue beds; exposure in the sports field in the town of Rakvere, northeastern Estonia, coll. by A. Öpik; Pl. I, fig. 1. 
Diagnosis. Size small for the subgenus (maximum known cephalic width approximately $32 \mathrm{~mm}$ ). Anterior cephalic margin weakly arched medially. Width of frontal glabellar lobe almost equal to median length of cephalon. Glabella sculptured with small scattered circular pitted tubercles of ordinary type (sensu Störmer, 1980).

Description. My material consists of seven incomplete cephalons and glabellas, three of which are figured here. Cephalon subparabolic in outline, twice as broad as long, transversely moderately convex, with narrow, laterally steeply sloping cheeks. Dorsal furrow almost straight but diverges in front of L3 somewhat abaxially. Preglabellar field very narrow and more conspicuous medially. L3 relatively narrow and long, occupying half of the length of glabella. L2 defined as a small roundish knob. Occipital ring with very small anterolateral notches. A young specimen shows relatively large, high, conical eyes located near L3 (Pl. I, figs. 2, 3). Genal spines not preserved in specimens available. Lateral border furrow faintly defined. Surface of glabella covered with disperse small circular pitted tubercles of equal size. Anterior border of cephalon and also the whole cheek show very weak granulation.

Only one incomplete, isolated pygidium is known from the contemporaneous beds together with isolated cephalons. This pygidium differs from those of $T$. (Schmidtops)-species and thus can be assigned with confidence to granuliferus (Pl. I, fig. 4). It is almost subcircular in outline, moderately convex in posterior view, with weakly sloping pleural areas, and narrow rachis. Pleural rings are relatively high and broad, especially the hindmost ones. Rachial rings are noticeably convex and well separated. Surface of pygidium is covered by fine granulation.

Discussion. This new species is one of the earliest representatives of the subgenus Toxochasmops (Toxochasmops) in the Ordovician of Baltoscandia. It differs from all other species of the subgenus in its peculiar glabellar sculpture, but in the general morphology of cephalon it resembles $T$. ( $T$.) inge from the overlying Oandu Stage. However, the latter species has a broader anterior border of cephalon, smaller eyes, and a different type of glabellar sculpture.

Occurrence. Keila Stage, Laagri Substage, Saue beds (lower Dicranograptus clingani Zone); exposure in the sports field in the town of Rakvere and Oandu River bank; northeastern Estonia.

Toxochasmops (Toxochasmops) notabilis sp. nov. Plate I, figures 5-10; Plate V, figure 7

Derivation of name. Latin notabilis, astonishing, alluding to peculiar sculpture of glabella. 
Holotype. Partially broken and worn-out cephalon (TUG 74-5) from the Oandu Stage, Hirmuse Formation, Oandu River bank, northeastern Estonia, coll. by A. Oraspõld; Pl. I, figs. 5-7.

Diagnosis. Small species for the subgenus (maximum known cephalic width $27 \mathrm{~mm}$ ). Cephalon twice as broad as long. Cheeks relatively high, with broad, well-defined lateral furrow. Eyes small, erect, narrow-conical. Length of L3 reaches a third of glabellar length. L2 conspicuous, knob-like. Pygidium subparabolic in outline, with relatively flat pleural areas. Glabellar sculpture consists of dispersed tubercles of various sizes.

Description. This rare species resembles in several features contemporaneous $T$. (T.) inge. Thus, in the description the distinctive characters are emphasized. Besides, the material available for examination is limited (three cephalons and two pygidia). Cephalon is narrowly subparabolic in outline with medially weakly upwardly arched anterior margin, whereas in inge the anterior margin is almost horizontal in anterior view. Frontal glabellar lobe does not overlap the anterior front of L3; the dorsal furrows are almost straight. S3 is straight, almost not sinuous abaxially like in granuliferus and inge. Preglabellar field is relatively broad, ridge-like, well developed, whereas in inge it is weak; preglabellar furrow deep (Pl. V, fig. 7). Eyes small, relatively low, and standing up on moderately high cheeks (Pl. I, figs. 6, 7). Occipital ring with noticeably well defined anterolateral notches, which in other contemporaneous species are weak. Genal spine relatively long, not high. Lateral furrow broad, well defined. Doublure narrow, moderately convex. Glabellar sculpture of well-defined roundish, relatively large tubercles of various sizes (Pl. V, fig. 7) is distinct among the species of the genus Toxochasmops. Preglabellar field, anterior border of cephalon, and also palpebral lobe and fixed cheeks are covered by fine dense granulation.

Posterior part of pygidium is bluntly parabolic in outline, not triangular as in inge and not acute-angled as in estonicus. Rachis low, with well-separated rings. Only $T$. (T.) wesenbergensis from the overlying Rakvere Stage has this type of pygidium.

Thorax and hypostoma unknown.

Discussion. This new species resembles most the contemporaneous species inge, but differs from it in the following main features. The cephalon is anteriorly lower and flatter. Eyes are much smaller and lower. The pygidium is generally subparabolic in outline and with broader rachis. The sculpture is rather peculiar. The congeneric new species estonicus is so different from notabilis that a detailed discussion of the distinguished features is not necessary.

The glabellar sculpture similar to notabilis was figured by Störmer (1980, pl. 27, fig. 3c) as Toxochasmops sp. nov. and another one by Owen (in Harper \& Owen, 1984, pl. 6, figs. 19, 20) as T. extensus. Corresponding specimens have been found from the contemporaneous beds of the Keila Stage, i.e. from the Nakkholmen Formation in Ringerike and the uppermost Furuberg Formation in 
Hadeland, Norway. Thus these species appeared in Norway earlier than notabilis in northern Estonia.

Occurrence. Oandu Stage, Hirmuse Formation (Dicranograptus clingani Zone); exposures in the town of Rakvere, Torrremägi, and Oandu River bank; northeastern Estonia.

\section{Toxochasmops (Toxochasmops) inge (Rõõmusoks, 1953)}

Plate I, figures 11-15; Plate V, figures 4-6

1953 Chasmops inge Rõõmusoks, p. 407, pl. I, figs. 1-3.

1970 Chasmops inge Rõõmusoks, p. 330.

1983 Chasmops inge Rõõmusoks, pl. IX, fig. 3.

1997 Chasmops inge Rõõmusoks, p. 235, photo 41-4.

Holotype. Almost complete cephalon [TUG 991-6 ( $\operatorname{Tr} 1038$ )], original of Rõõmusoks (1953, p. 407, pl. I, figs. 1, 2) from the Oandu Stage, Hirmuse Formation, Oandu River bank, northeastern Estonia, coll. by A. Öpik.

Diagnosis. Small species for the subgenus (maximum known cephalic width approximately $26 \mathrm{~mm}$ ). Anterior margin of cephalon almost horizontal in anterior view. L1 strongly developed and splitting laterally in two small short parts $(\mathrm{Pl}$. V, fig. 5). L3 narrow, oblong, and by half shorter than glabella. Eyes relatively high, thick-conical. Pygidium triangular in outline, acute-angled in posterior view. Rachis conspicuously narrow, well defined. All parts of cephalon and pygidium covered with fine dense and even granulation.

Description. Cephalon moderately low, twice as broad as long, with anterior margin reaching medially narrowly forwards. Glabella transversely moderately convex. Preglabellar field narrow, developed medially only. Width of frontal glabellar lobe equal to cephalic length. L2 very small. L3 narrow, oblong, half of the length of glabella. Frontal glabellar lobe overlaps the front of L3 anterolaterally. S3 considerably sinuous abaxially. Occipital ring with weak anterolateral notches. Eyes thick-conical, relatively high, and inclined forwards. Cheeks low and weakly slanting laterally. Genal spine moderately high, anteriorly getting evenly lower backwards. Lateral furrow narrow but well developed. Doublure narrow, convex, becoming broader and flatter anteromedially. Cephalic sculpture consists of fine, dense, and even granulation (Pl. V, fig. 6).

Pygidium acute-angled in posterior view (PI. I, fig. 15), with relatively narrow convex rachis which rises well to the fore. Outer portion of pleural area steeply sloping. There are 15 or 16 pleural rings.

Thorax and hypostoma unknown.

Discussion. McNamara (1980a) stated that nominal species macrourus, maximus, and inge are junior synonyms of Toxochasmops extensus. However, inge differs 
markedly from both $T$. (Schmidtops) maximus and the lectotype specimen of $T$. (T.) extensus in having smaller size, relatively smaller frontal glabellar lobe, different lobation of glabella, larger and higher eyes, positioned near L3, smaller and lower genal spines, and flatter pygidium with narrower pleural rings. The sculpture of fine dense granules (Pl. V, fig. 6) is also distinctive. On the other hand, the species concept of $T$. (T.) extensus of McNamara appears to be somewhat vague. The cephalons from the erratic boulders in Germany figured by McNamara (1980a, pl. 1, figs. 8-10, 12, 13; 1980b, fig. 2G-J) are evidently very different from the lectotype of extensus figured by Störmer (1940, pl. 3, figs. 7-9), particularly by highly arched anterior margin, higher and broader glabella, and larger L3.

A related species, figured here for comparison (Pl. III, fig. 11) as $T$. (T.) aff. inge, differs from our species in having the same general appearance but a shorter frontal glabellar lobe, broader and anteriorly more acute L3, laterally not splitted L1, and enlarged eyes.

Occurrence. Oandu Stage, Hirmuse Formation (Dicranograptus clingani Zone); exposures in the town of Rakvere, Tõrremägi, and Oandu River bank; northeastern Estonia.

Toxochasmops (Toxochasmops) estonicus sp. nov.

Plate II, figures 1-10

1953 Chasmops macrourus (Sjögren); Rõõmusoks, p. 409, pl. I, figs. 7-8.

1970 Chasmops extensus (Boeck); Rõõmusoks, p. 330.

Derivation of name. Latin estonicus, inhabitant of Estonia.

Holotype. Partially broken cephalon [TUG 991-9 (Tr 1012)] from the Oandu Stage, Hirmuse Formation, exposure in the town of Rakvere, northeastern Estonia, coll. by A. Öpik; Pl. II, figs. 4-6.

Diagnosis. Size average for the subgenus (maximum known cephalic width approximately $46 \mathrm{~mm}$ ). Cephalon comparatively flat and low. Anterior margin moderately arched medially in anterior view. Cephalic doublure narrow, gently convex. Eyes bluntly-conical, positioned near the centre of cheeks. Preglabellar field reaching across the middle third of frontal glabellar lobe. L3 large, L2 as a conspicuous knob. Pygidium high, broadly triangular in outline, with acute-angled top.

Description. Cephalon semicircular or subparabolic in outline. Frontal glabellar lobe gently convex sagitally, sloping noticeably to anterior margin; lobe width equal to cephalic length. Dorsal furrow deep, almost straight, but placed gently aside from L3. S3 slightly sinuous abaxially only. Preglabellar field well developed, ridge-like; preglabellar furrow relatively deep. Genal spine long, 
relatively elevated anteriorly, but uniformly lowering backwards. Cheeks low, laterally strongly convex. Lateral furrow broad, well defined. Occipital ring broad, short, with weakly developed anterolateral notches. Cephalic sculpture of fine dense granulation and large disperse composite tubercles (Pl. II, fig. 6).

No completely preserved pygidia were available for examination. The topmost part of pygidium broadly triangular, with strongly convex pleural areas and relatively broad rachis. Pleural rings on topmost part turned backwards. Pygidial margin in posterior view acute-angled.

Thorax and hypostoma unknown.

Discussion. It is beyond the scope of the present paper to discuss more closely the problems concerning the Scandinavian species macrourus and extensus. This would require a more profound examination of topotype specimens, which was stressed already by Störmer $(1940$, p. 138). While discussing the species Chasmops extensa, he wrote: "It seems possible that the Swedish species Chasmops macroura Sjögren, described by Angelin (1851, p. 9, pl. 7, figs. 3, 4) might be identical with the present form. They correspond in the major characteristics, but the identity has to be solved after a study of the type specimen of C. macroura." Unfortunately, the holotype of the latter species has not yet been discovered (see above). Nevertheless, earlier, and not without a reason, the present author (Rõõmusoks, 1953) named the species described here macrourus. The specimen figured by Angelin has several cephalic features closely similar to the Estonian form, except for evidently shorter genal spines, slightly larger eyes, and a lower foremost part of the frontal glabellar lobe in lateral view. The photos of two specimens from the Gräsgård Siltstone erratic blocks from Öland Island, Sweden (Pl. II, figs. 11-13; Pl. VI, fig. 5) depict probably the true macrourus. The glabellar sculpture of macrourus is unknown in detail, but there are at least disperse large tubercles. A very similar new species, larger than estonicus, is represented by a well-preserved specimen (RM D403) from the Molda Topoformation (equivalent of the Oandu Stage) from Kullsberg, Dalarna, Sweden (Pl. VI, fig. 6). A pygidium, figured by Warburg (1925, pl. XI, figs. 23, 24) as Chasmops macrourus, may be possibly referred to the same species.

To sum up, we may conclude that in the Oandu time a new group of more or less related species appeared in the Baltoscandian region, forming a separate $T$. (T.) extensus species-group.

Our new species, discussed above, is (together with vormsiensis) the biggest representative of the subgenus in the Ordovician of Estonia. It differs from all other species in a relatively flat and broad cephalon, long and high genal spines, comparatively large eyes positioned near the centre of the cheeks, and in broadly triangular high pygidium. The glabellar sculpture resembles that of wesenbergensis only. A form, found in the Oandu Stage in some drillcores of southern Estonia (Laeva and Karula) and Lithuania (Ukmerge and Krekenava), and identified by Männil (1966) as Chasmops cf. extensa, may also represent a new species of Toxochasmops (Toxochasmops). 
Occurrence. Oandu Stage, Hirmuse Formation (Dicranograptus clingani Zone); exposures in the town of Rakvere, Tõrremägi, and Oandu River bank.

Toxochasmops (Toxochasmops) wesenbergensis (Schmidt, 1881)

Plate III, figures 1-10; Plate VI, figure 1

1881 Phacops (Chasmops) wesenbergensis Schmidt, p. 115, pl. IV, fig. 11; pl. V, figs. 1-7; pl. X, fig. 20.

1907 Phacops (Chasmops) wesenbergensis Schmidt, p. 7.

1953 Chasmops wesenbergensis Schmidt; Rõõmusoks, p. 412.

Lectotype. Selected herein: nearly complete cephalon (4248/81; Pal. Inst. Russian Acad. of Sciences, Moscow), original of Schmidt, 1881, pl. IV, figs. 11a,b, from the Rakvere Stage, Piilse Formation, Rägavere exposure in the town of Rakvere, northeastern Estonia.

Diagnosis. Size medium for the subgenus (maximum cephalic width $45 \mathrm{~mm}$ ). Cephalon low, weakly convex in both sagittal and transverse directions. Frontal glabellar lobe relatively broad but short. Preglabellar field extremely narrow or reduced. L3 very small as compared to the size of frontal glabellar lobe and obtusely triangular. L2 extremely small or reduced. Pygidium flat, broadly parabolic in outline and with subcircular posterior margin.

Description. Cephalon comparatively low, broadly subparabolic in outline. Width of frontal glabellar lobe larger than cephalic length, lateral parts of lobe narrowly expanded. Cephalic margin almost horizontal in anterior view to gently arched medially. Doublure narrow and uniformly convex. Cheeks relatively high, with steeply slanting outer side. Genal spines long, relatively low, getting evenly lower backwards. Lateral border furrow weakly expressed. Dorsal furrows deep, almost straight. Occipital furrow also deep, well defined. Occipital ring with strongly developed anterolateral notches (Pl. III, fig. 1). Eyes comparatively large, high, and bluntly-conical, situated in the centre of cheeks. Posterior section of facial suture runs in a wide deep furrow. Glabella provided with fine granulation and disperse composite tubercles, cheeks and doublure with simple granulation, but genal spines are covered by ultrafine granules. Hypostoma distinctly different from that in the species of Toxochasmops (Schmidtops). Median body weakly convex, maculae small, posterior border narrow, and anterior wing very short. Surface of median body weakly pitted.

Pygidium conspicuously flat. Pleural areas weakly sloping; rachis more or less wide anteriorly and relatively low. Pleural rings, 12-14 in number, broad, turning obliquely backwards. 


\section{PLATE I}

Figs. 1-4. Toxochasmops (Toxochasmops) granuliferus sp. nov.; Keila Stage, Laagri Substage, Saue beds; northeastern Estonia. 1, TUG 991-4, holotype; exposure on the sports field in the town of Rakvere; coll. by A. Öpik; dorsal view, × 2. 2-3, TUG 991-2; exposure ibid.; anterior and dorsal views, $\times 3.3$ and $\times 4$, respectively. 4 , TUG 991-5; exposure ibid.; dorsal view, $\times 2$.

Figs. 5-10. Toxochasmops (Toxochasmops) notabilis sp. nov.; Oandu Stage, Hirmuse Formation; northeastern Estonia. 5-7, TUG 74-5, holotype; Oandu River bank; coll. by A. Oraspõld; dorsal, lateral, and anterior views, $\times 2$. 8, TUG 990-5; exposure on Freedom square in the town of Rakvere; dorsal view of glabella, $\times 2$. 9, TUG 990-10; exposure in Rakvere; dorsal view, $\times 2$. 10, TUG 991-8 (Tr 1042); Tõrremägi; dorsal view, $\times 2$.

Figs. 11-15. Toxochasmops (Toxochasmops) inge (Rõõmusoks, 1953); Oandu Stage, Hirmuse Formation; northeastern Estonia. 11-13, TUG 991-6 (Tr 1038), holotype; Oandu River bank; coll. by A. Öpik; dorsal, anterior, and lateral views, $\times 2$; figured by the author, 1953, pl. I, figs. 1-2. 14-15, TUG 991-7 (Tr 1039); Oandu River bank; dorsal and posterior views, $\times 4$; dorsal view, figured by the author, 1953, pl. I, fig. 3.

\section{PLATE II}

Figs. 1-10. Toxochasmops (Toxochasmops) estonicus sp. nov.; Oandu Stage, Hirmuse Formation; northeastern Estonia and Ingria. 1-3, TUG 991-101 (Tr 1014); Rakvere; dorsal, posterior, and lateral views, $\times 2, \times 2$, and $\times 1.5$, respectively. 4-6, TUG 991-9 $(\operatorname{Tr} 1012)$, holotype; Rakvere; coll. by A. Öpik; anterior and dorsal views, $\times 1$, cranidium $\times 4$. 7-10, TUG 990-8; Pljussa River bank near Polje, Ingria; coll. by the author 1955 ; dorsal, anterior, ventral, and lateral views, $\times 1$.

Figs. 11-13. Toxochasmops (Toxochasmops) macrourus (Angelin, 1851); Gräsgård Siltstone boulder, Öland Island. 11-12, RM Ar 23 577; Hulterstad block; lateral and anterior views, $\times 2.13$, PIU ar 15555; Gräsgård; dorsal view, $\times 2$.

\section{PLATE III}

Figs. 1-10. Toxochasmops (Toxochasmops) wesenbergensis (Schmidt, 1881); Rakvere Stage; exposures in the town of Rakvere, northern Estonia. 1-3, TUG 990-4; dorsal, anterior, and lateral views, $\times 2$. 4-5, TUG 990-2; coll. by the author, 1942; dorsal and posterior views, $\times 2$. 6-7, TUG 990-3; anterior and dorsal views, $\times 2$. 8, TUG 2-279; dorsal view, $\times 1.6$. 9, TUG 993-618; lateral view, $\times 2$. 10, TUG 990-15; coll. by the author, 1942; dorsal view, $\times 1$.

Fig. 11. Toxochasmops (Toxochasmops) aff. inge (Rõõmusoks, 1953); Gräsgård Siltstone erratic boulder; Gräsgård, Öland Island; coll. by N. P. Angelin. RM Ar 23391; dorsal view, $\times 2$.

\section{PLATE IV}

Figs. 1-10. Toxochasmops (Toxochasmops) vormsiensis sp. nov.; Vormsi Stage, Kõrgessaare Formation; northwestern Estonia. 1, TUG 990-14a, holotype; Saxby coast, Vormsi Island; coll. by the author, 1969; dorsal view of internal mould, $\times$ 1.4. 2-3, TUG 990-14b; ibid. exposure; dorsal and lateral views, $\times 1$ (on the lower part of the sample glabella TUG 990-14a). 4-5, TUG 990-7; Mõnuste, coll. by the author, 1953; dorsal and anterior views of the internal mould, $\times 1$. 6, TUG 79-119; Kärrslätt, Vormsi Island; coll. by V. Jaanusson; dorsal view, $\times 4$. 7, TUG 36-29; Lyckholm; coll by B. Stein; dorsal view of internal mould, $\times$ 1. 8-9, TUG 990-1; Saxby coast, Vormsi Island; coll. by the author, 1942; dorsal and posterior views of internal mould; $\times 1.3$. 10, TUG 990-13; Saxby coast, Vormsi Island; internal view, $\times 2$. 
PLATE I
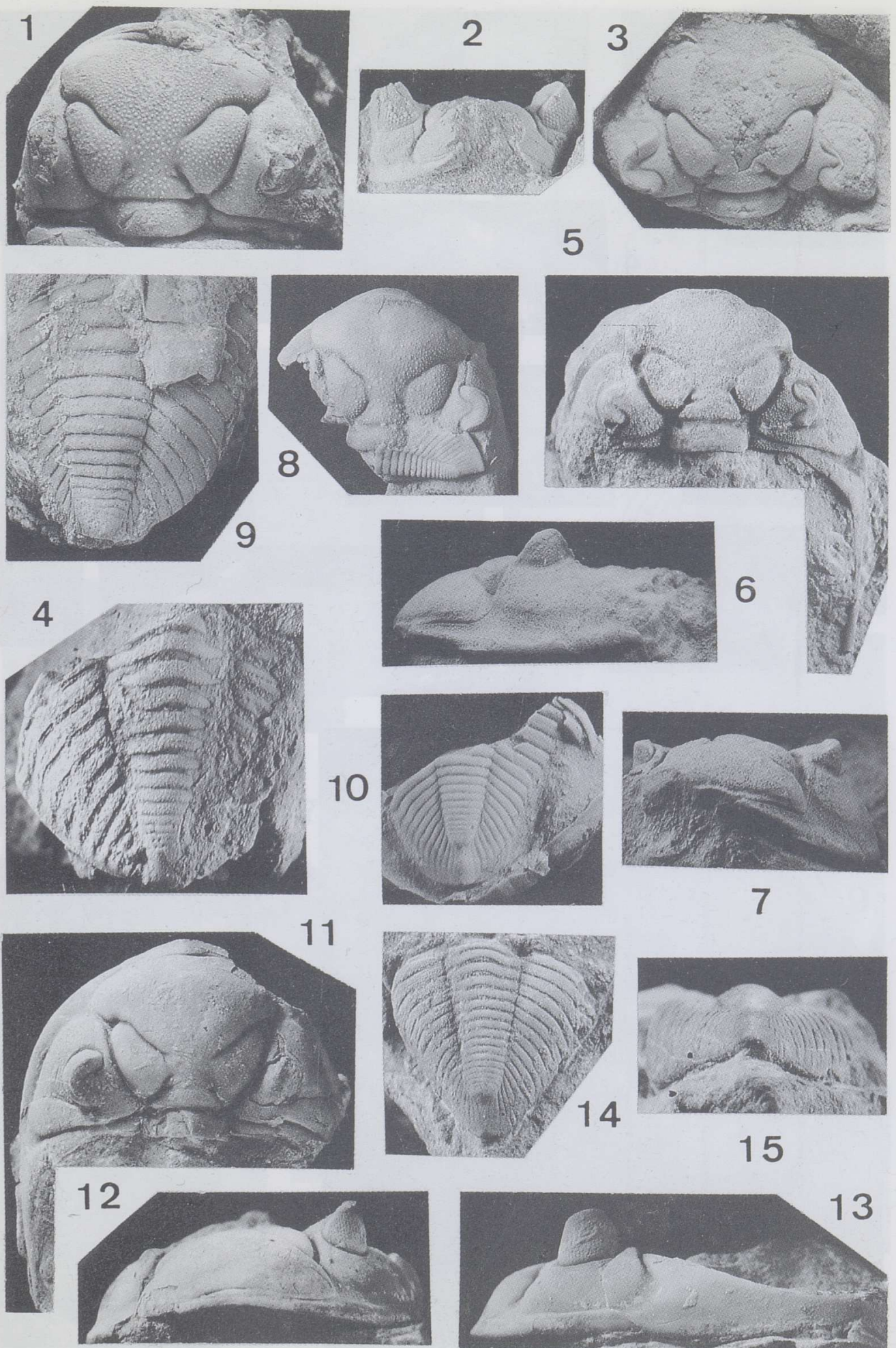

15

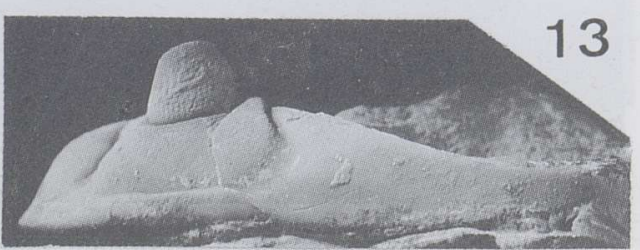


PLATE II
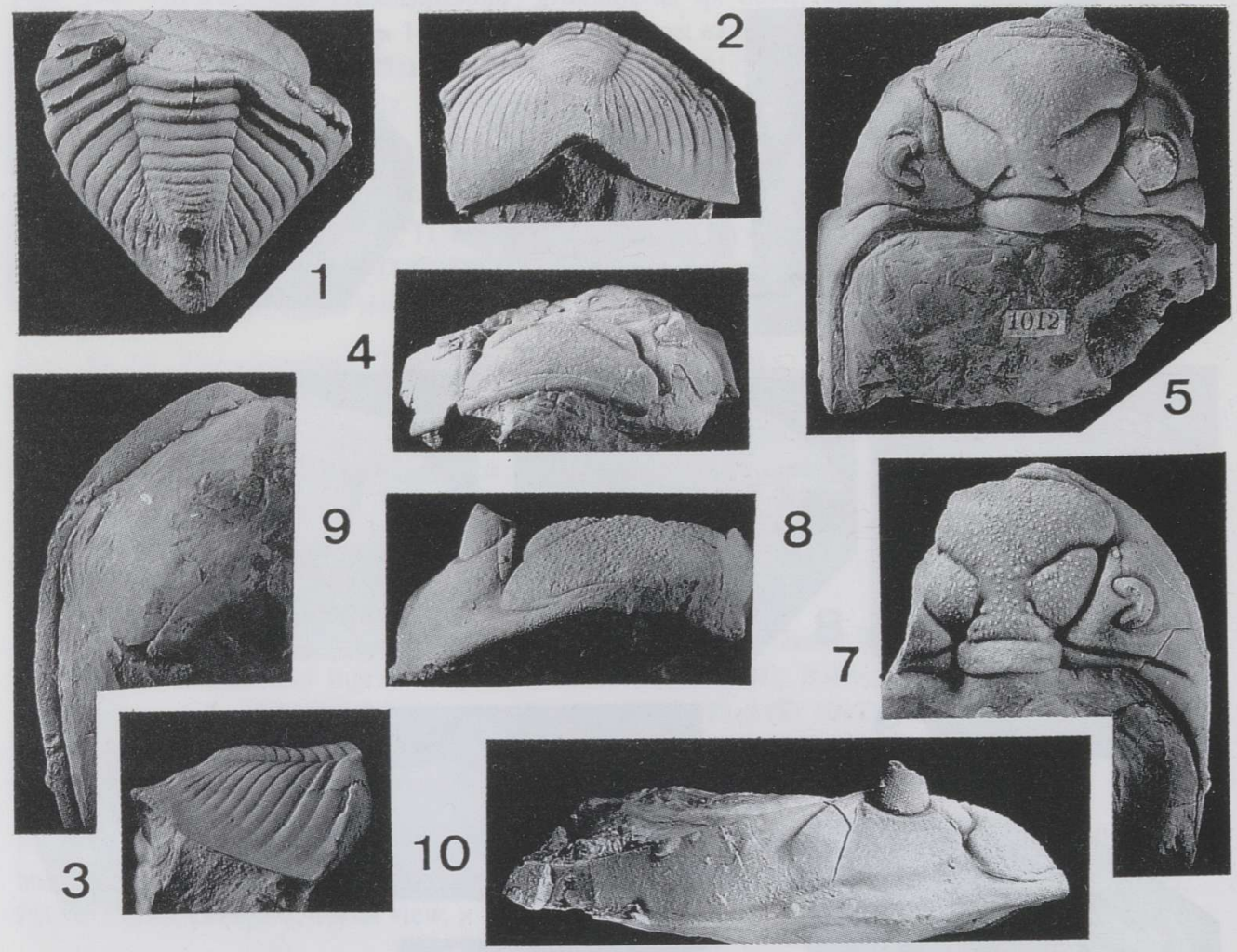

$$
\text { I. } 8 x^{2}
$$
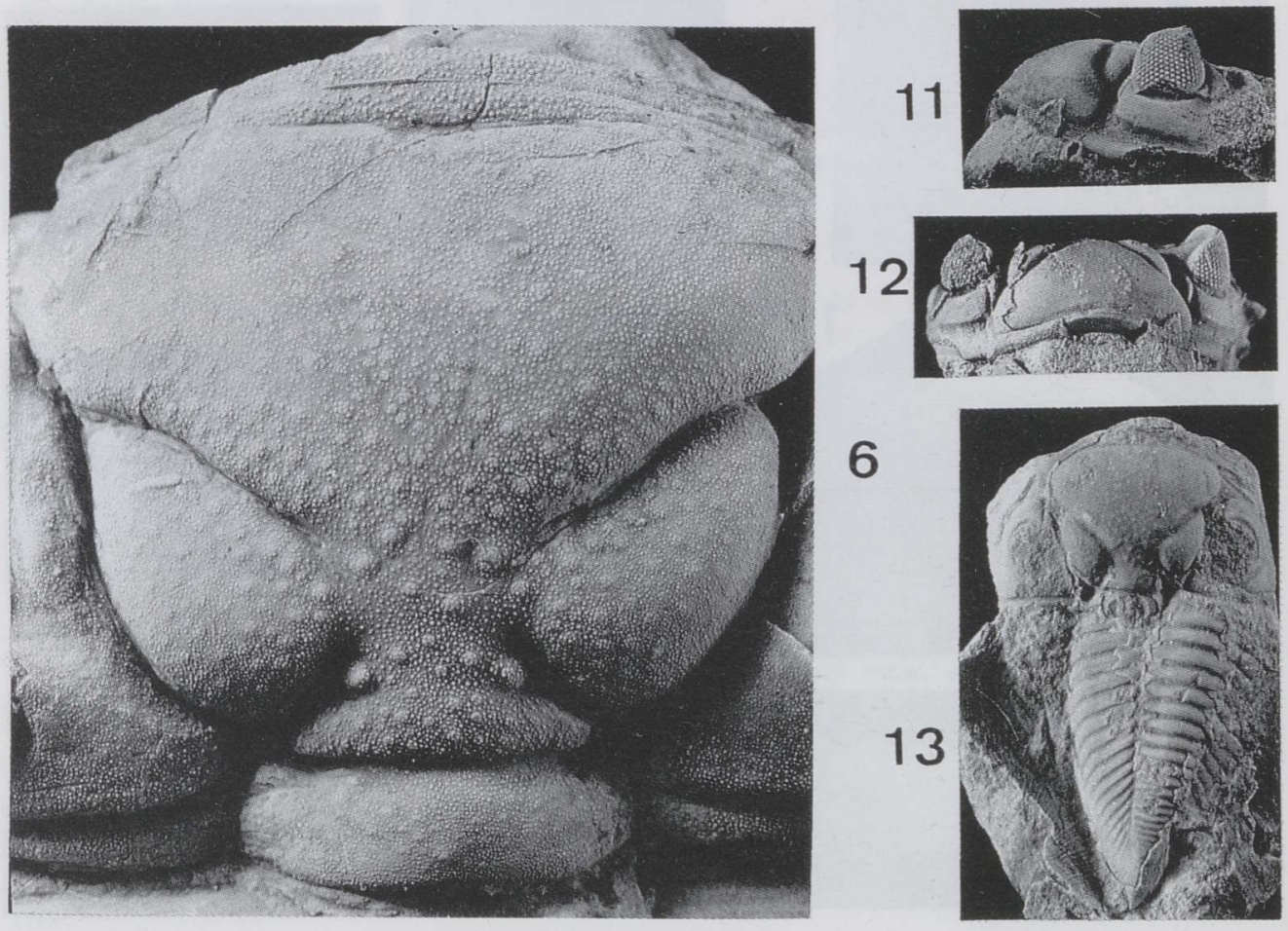
PLATE III
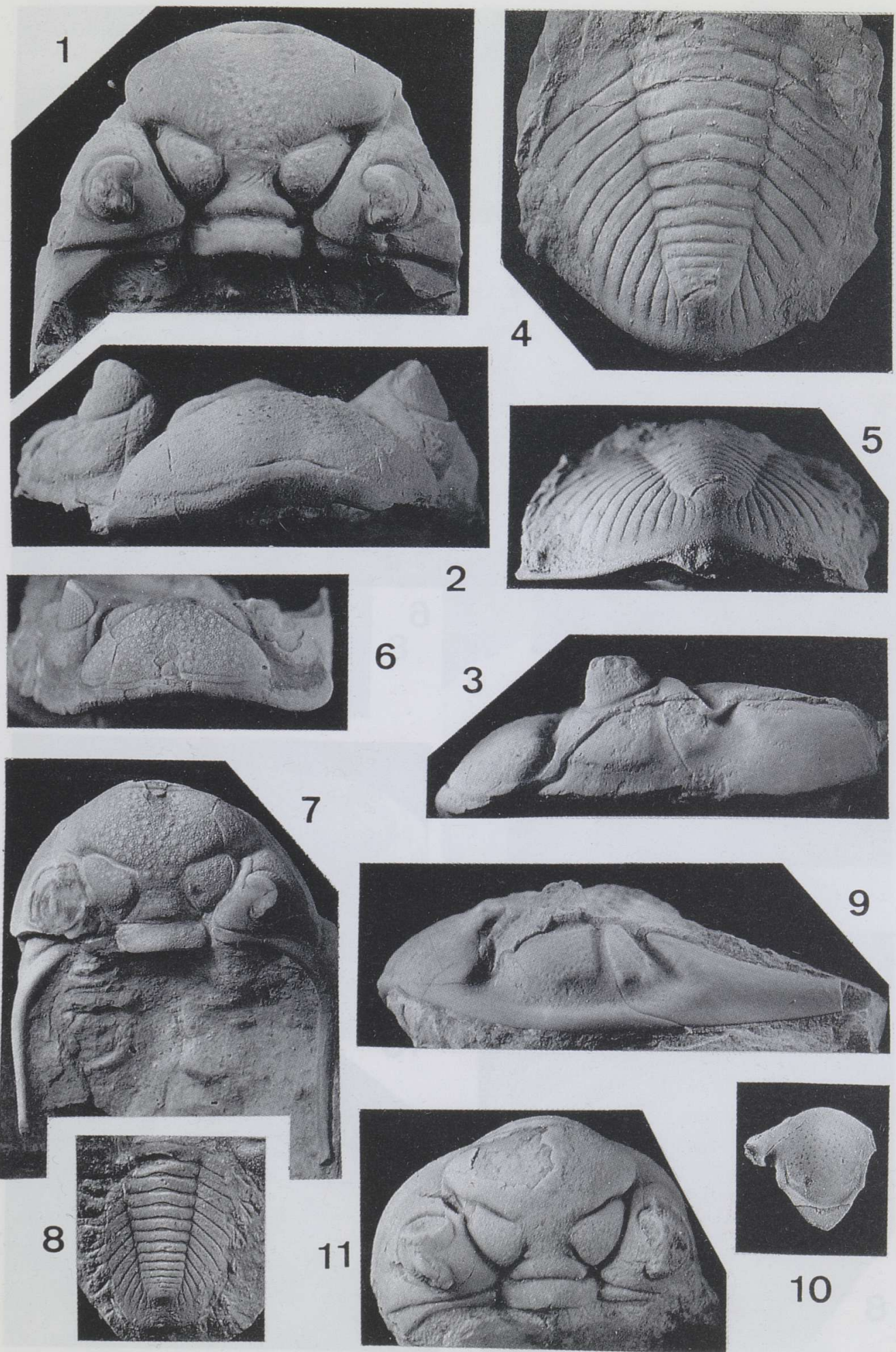

10 
PLATE IV

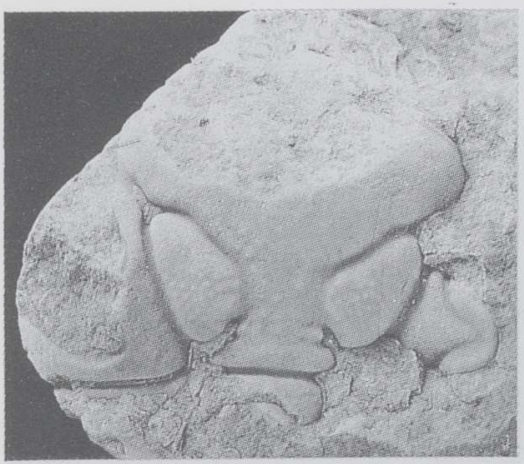

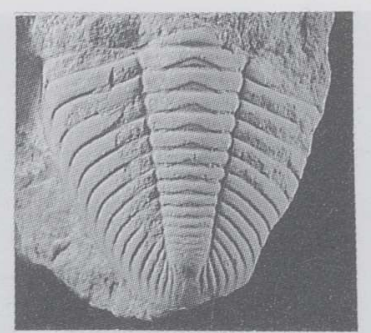

2

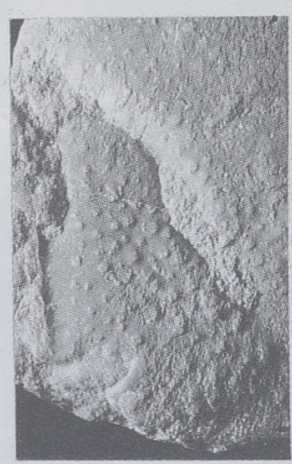

6

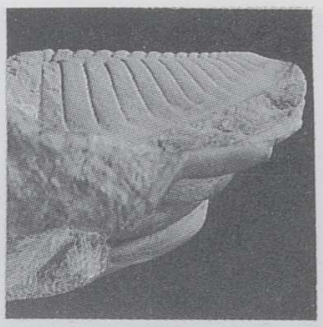

3

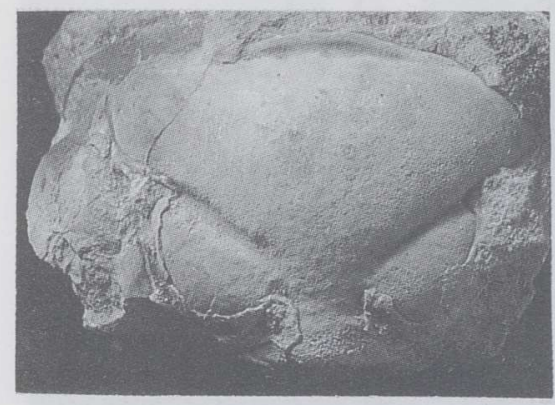

4

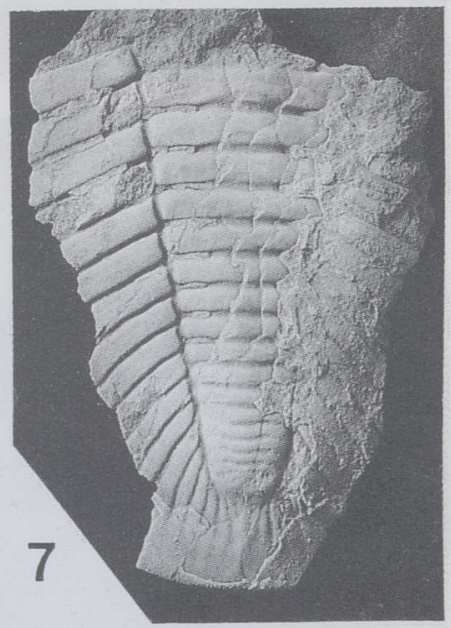

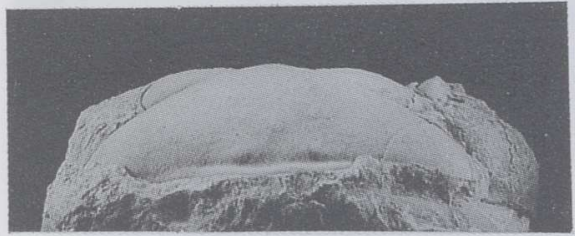

5

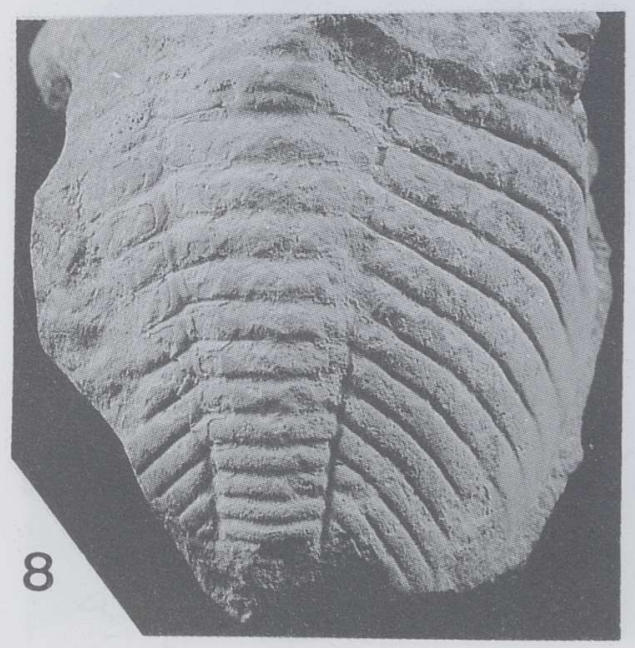

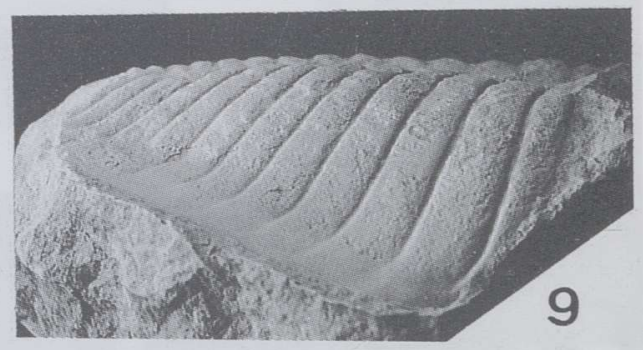

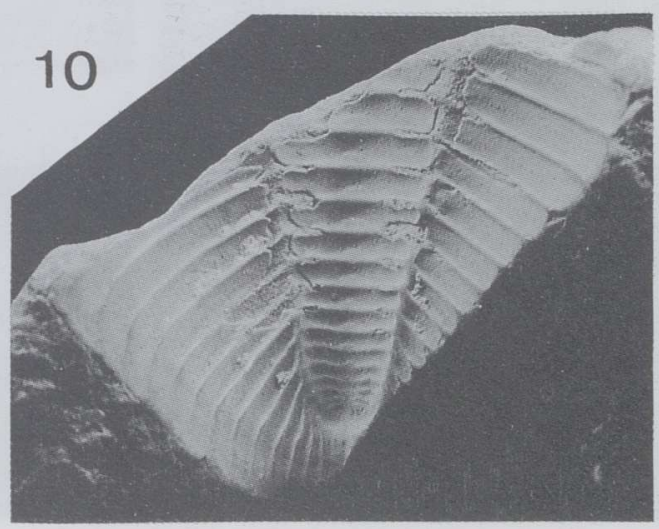


PLATE V
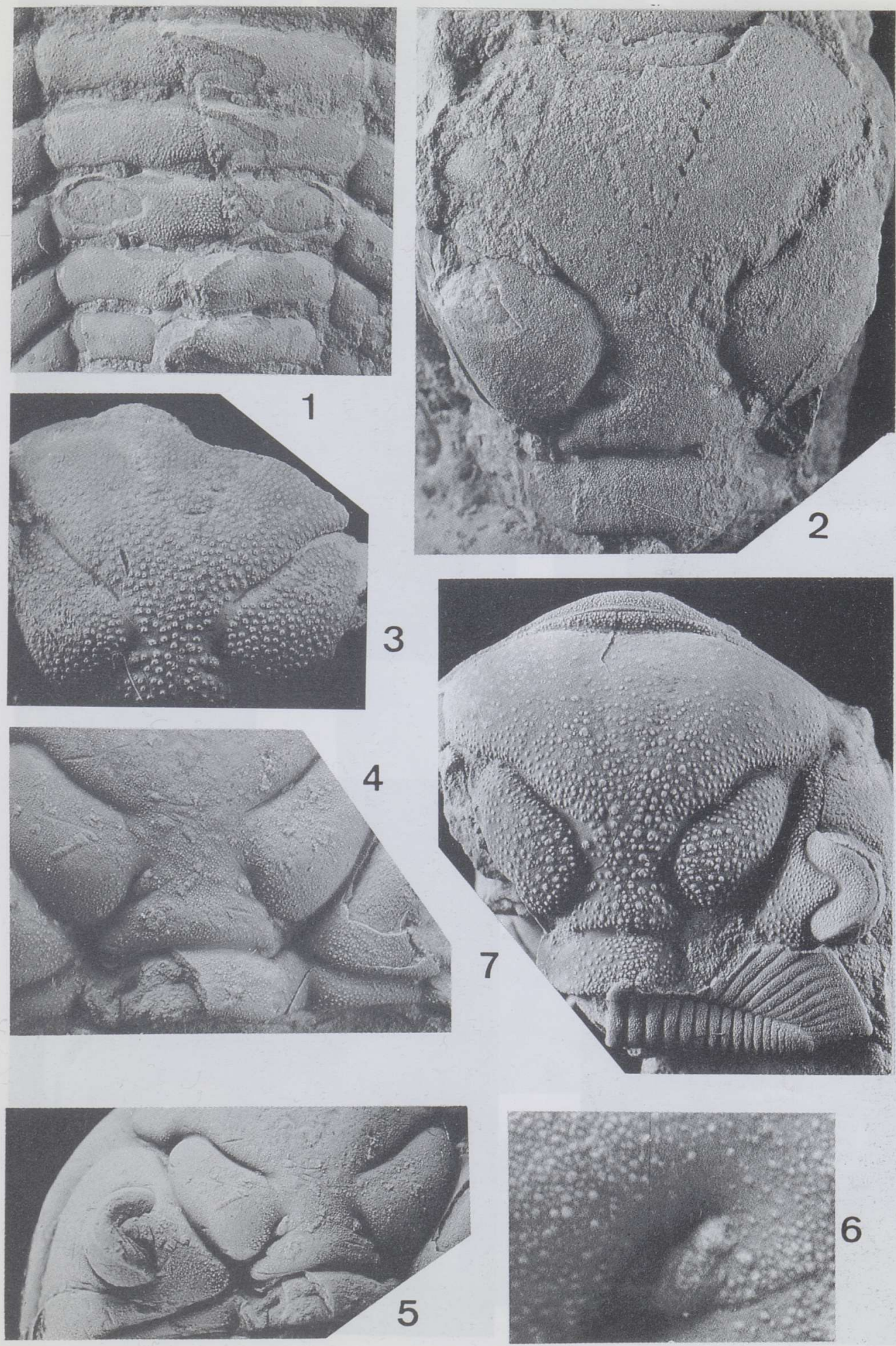
PLATE VI
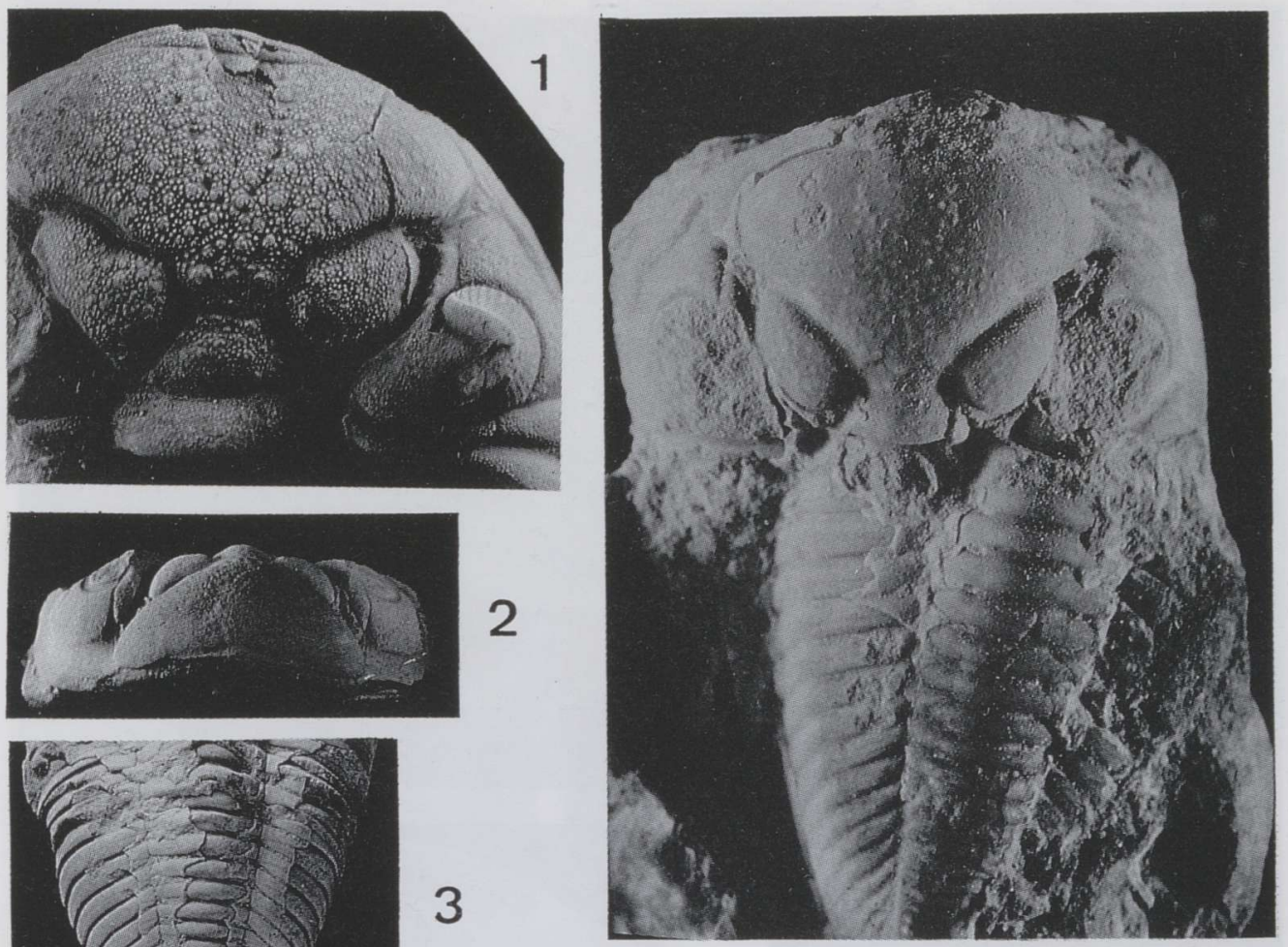

2

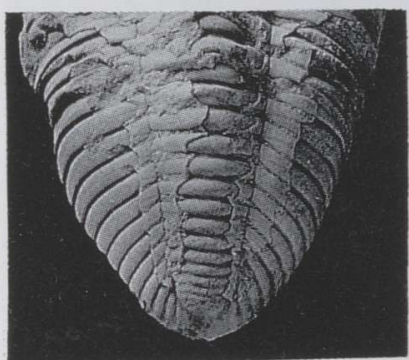

3
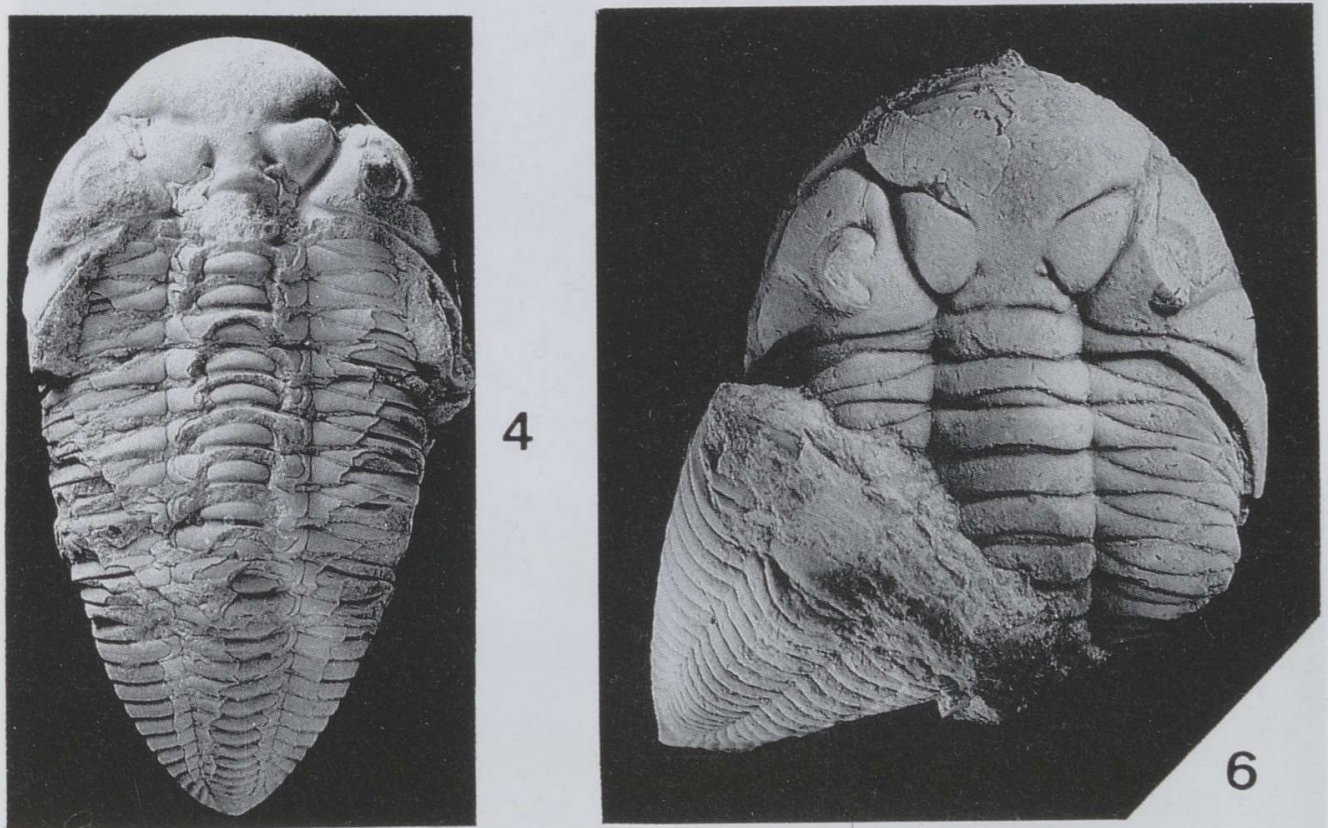
PLATE VII
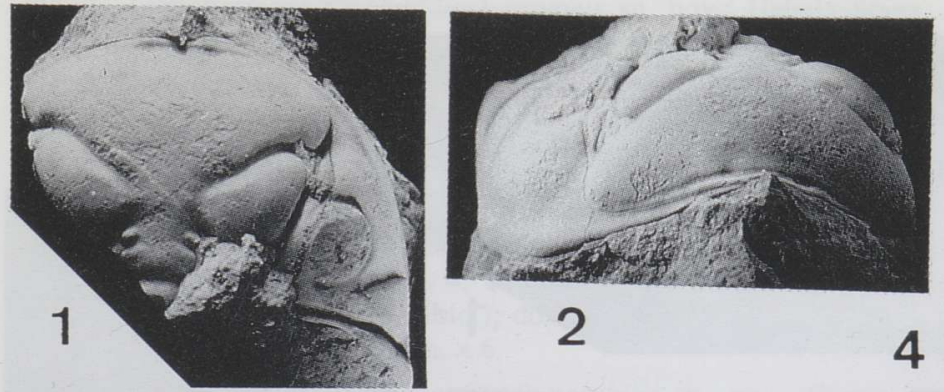
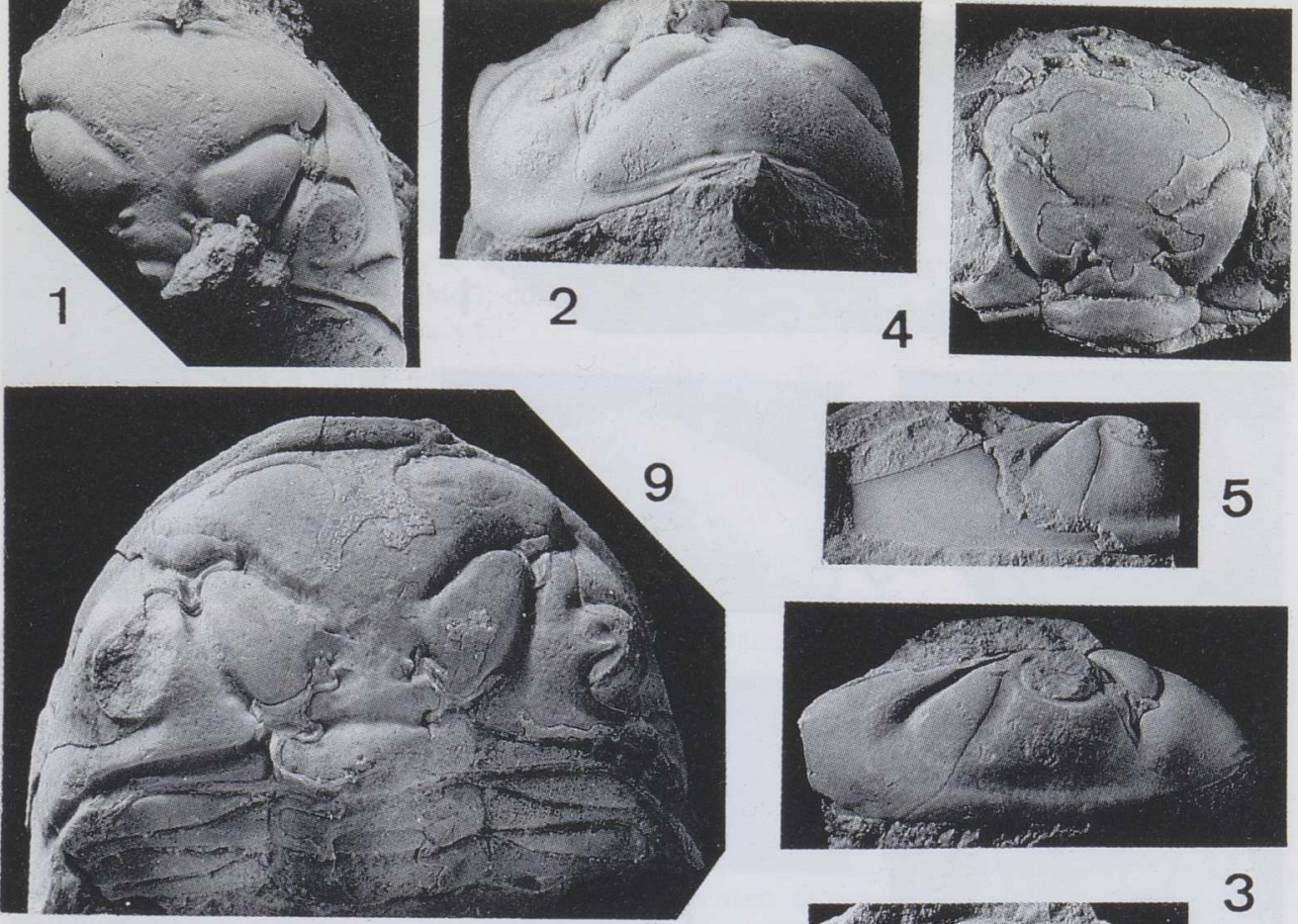
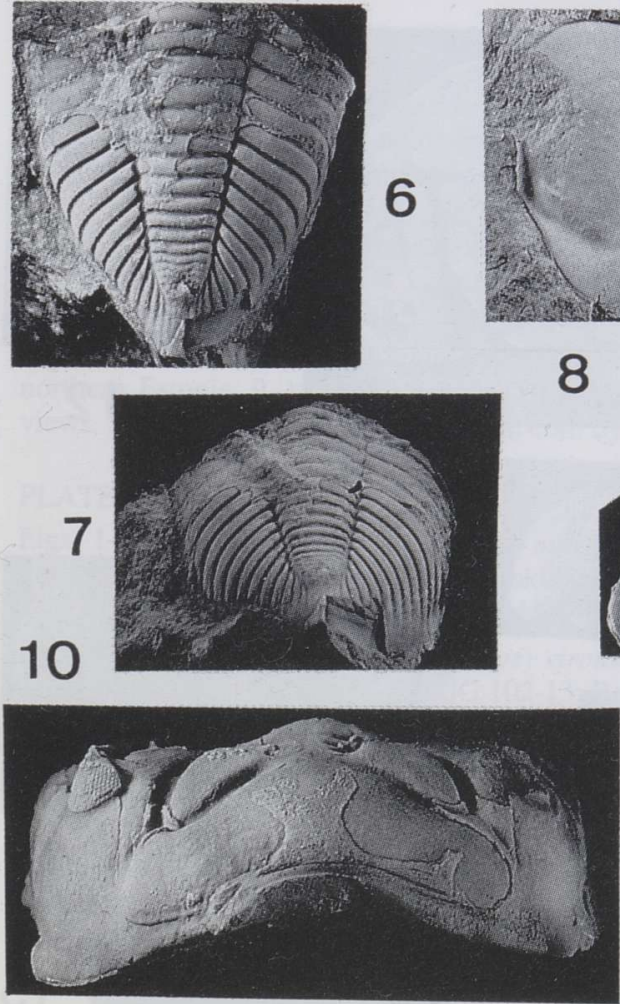
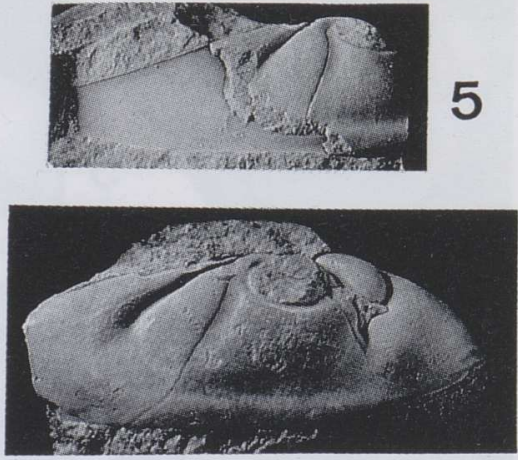

3
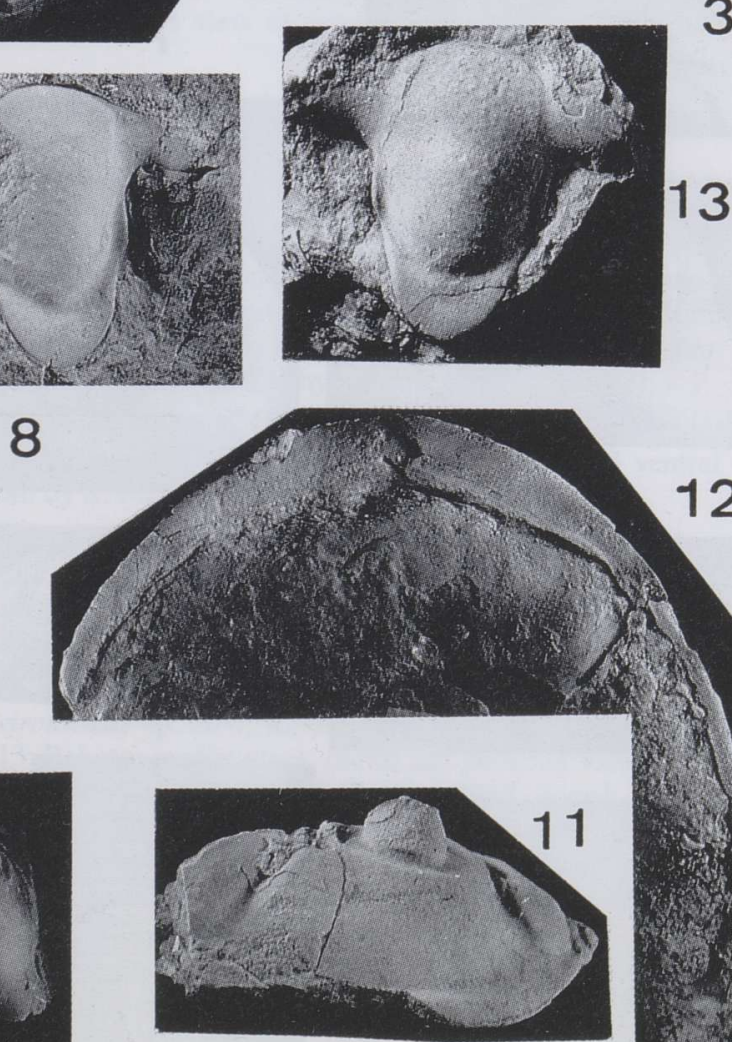
PLATE VIII
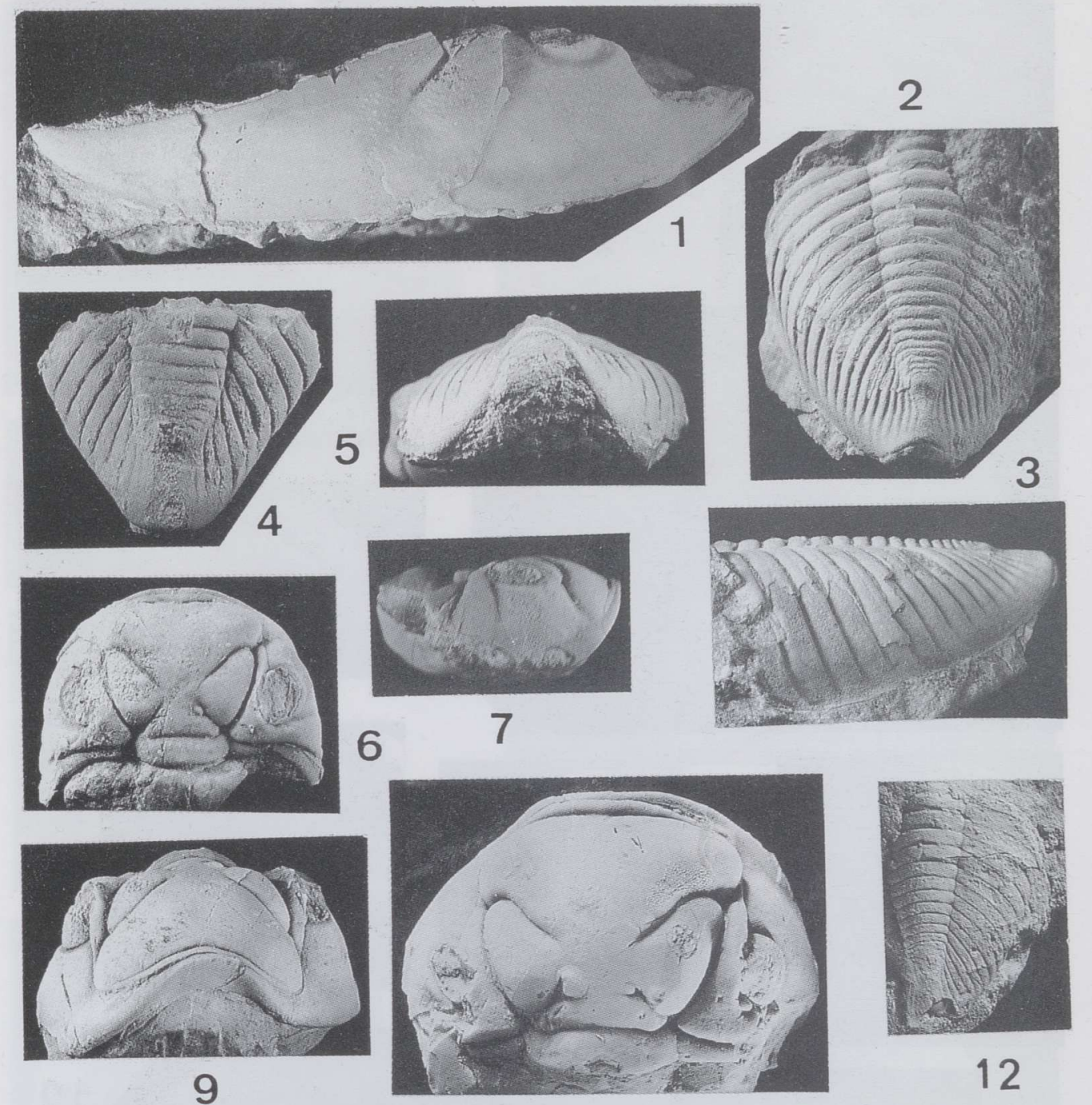

9
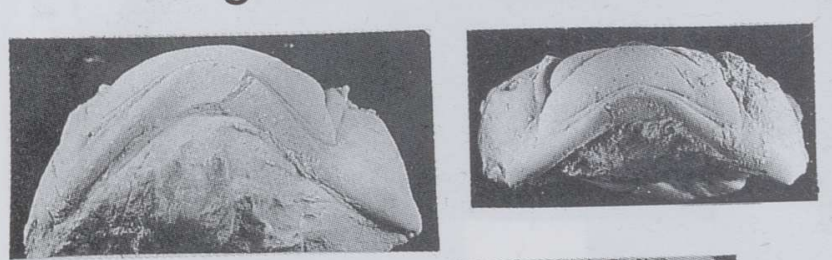

10

12
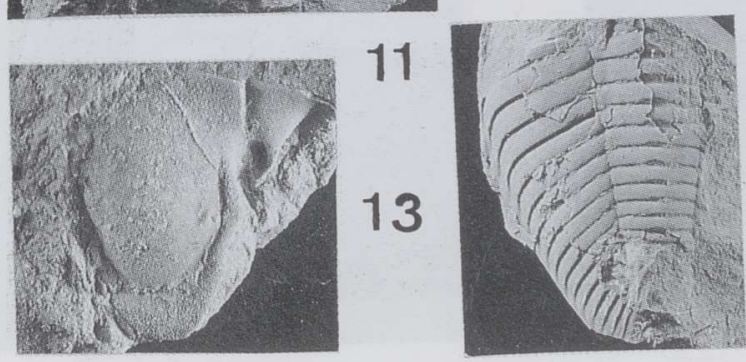

8

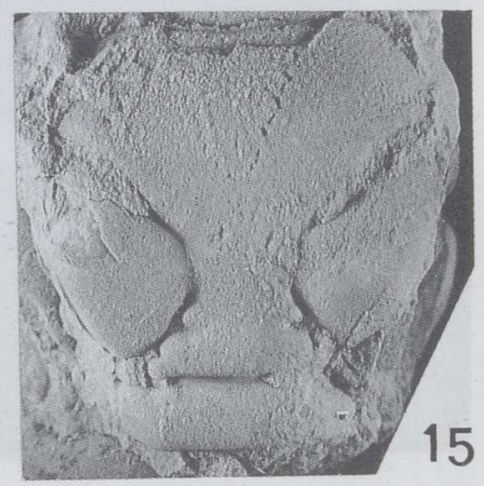




\section{PLATE V}

Fig. 1. Toxochasmops (Schmidtops) proavus sp. nov.; Haljala Stage, Jõhvi Substage; Aluvere, northern Estonia; TUG 990-16; coll. by the author, 1962; dorsal view, $\times 4$.

Fig. 2. Toxochasmops (Schmidtops) sp. nov.; Gräsgård Siltstone erratic boulder, Segerstad, Öland Island, Sweden; RM Ar 55357, old collection; dorsal view, $\times 3.6$.

Fig. 3. Toxochasmops (Toxochasmops) granuliferus sp. nov.; Keila Stage, Laagri Substage, Saue beds; northeastern Estonia. TUG 992-1; Oandu River bank; dorsal view, $\times 2.3$.

Figs. 4-6. Toxochasmops (Toxochasmops) inge (Rõõmusoks, 1953); Oandu Stage, Hirmuse Formation; northeastern Estonia. 4, TUG 991-6 (Tr 1038), holotype; Oandu River bank; coll. by A. Öpik; dorsal view, $\times 5$. 5, (ibid.); dorsal view showing L1, × 3.5. 6, (ibid.); dorsal view of L3-L2 with the finest granulation, $\times 6$.

Fig. 7. Toxochasmops (Toxochasmops) notabilis sp. nov.; Oandu Stage, Hirmuse Formation; northeastern Estonia. TUG 990-5; exposure on Freedom square in the town of Rakvere; dorsal view of glabella, $\times 5$. Pygidium belongs to $T$. $(T$. $)$ inge.

\section{PLATE VI}

Fig. 1. Toxochasmops (Toxochasmops) wesenbergensis (Schmidt, 1881); Rakvere Stage; exposure in the town of Rakvere, northern Estonia. TUG 990-3; dorsal view, $\times 4$.

Figs. 2-4. Toxochasmops (Toxochasmops) sp. nov.; stratigraphic level unknown, erratic specimen from Hiiumaa Island, northwestern Estonia; coll. by E. Eichwald. Museum of Palaeontology and Stratigraphy, University of St Petersburg, 149/1; anterior and dorsal views of internal mould, $\times 1$. Original by Schmidt, 1881, pl. IV, fig. 10.

Fig. 5. Toxochasmops (Toxochasmops) macrourus (Angelin, 1851); Gräsgård Siltstone boulder, Öland Island, Sweden. Gräsgård. PIU ar 15555; dorsal view of internal mould, × 3.5.

Fig. 6. Toxochasmops (Toxochasmops) sp. nov.; RM D403; Moldå Topoformation, Kullsberg, Dalarna, Sweden; coll. by V. Jaanusson, 1946; dorsal view of internal mould of cephalon and pygidium, $\times 1$.

\section{PLATE VII}

Figs. 1-8. Toxochasmops (Schmidtops) proavus sp. nov.; Haljala Stage, Jõhvi Substage; northern Estonia. 1-3, TUG 990-11, holotype; Keila, northeastern quarry; coll. by the author, 1964; dorsal, anterior, and lateral views (internal moulds), × 1. 4, TUG 990-17; Alliku; coll. by the author, 1964; dorsal view, $\times 1$. 5, TUG 991-11; Spitham, coll. by A. Öpik; lateral view of cephalon (internal mould), $\times 1$. 6-7, TUG 990-12; Aluvere; coll. by the author, 1966; dorsal and posterior views of pygidium (internal mould), $\times 1.2$ and $\times 1$, respectively. 8, TUG 79-120; Keila Stage, Ristna beds; Pääsküla, northwestern Estonia; coll. by V. Jaanusson, 1941; dorsal view of hypostoma (internal mould), $\times 1$.

Figs. 9-13. Toxochasmops (Schmidtops) maximus (Schmidt, 1881); Keila Stage, Laagri Substage; northern Estonia. 9-12, TUG 3-341; Lilli; coll. by A. Wahl; dorsal, anterior, lateral, and ventral views, × 1. 13, TUG 993-120; Pääsküla; coll. by R. Männil; dorsal view (internal mould), $\times 1$.

\section{PLATE VIII}

Figs. 1-3. Toxochasmops (Schmidtops) maximus (Schmidt, 1881); Keila Stage, Laagri Substage; northern Estonia. 1, TUG 993-352; Pääsküla; coll. by R. Männil; lateral view (internal mould), $\times 1$. 2-3, TUG 990-9; Keila quarry; dorsal and lateral views (internal mould), $\times 0.9$ and $\times 1$, respectively.

Figs. 4-13. Toxochasmops (Schmidtops) vironiensis sp. nov.; Keila Stage, Laagri Substage, Saue beds; northeastern Estonia. 4-5, TUG 102-13; Rakvere market place; dorsal and posterior views, $\times 2$. 6-8, TUG 990-6 (Tr 1065), holotype; Oandu River bank; coll. by the author, 1947; dorsal, lateral, and anterior views, × 1. 9-11, TUG 991-1 (Tr 1083); Rakvere; coll. by A. Öpik; anterior, dorsal, and oblique-anterior views, $\times 1, \times 1.8$, and $\times 1$, respectively. 12, TUG 102-12; Rakvere; coll. by H. Palmre; dorsal view, $\times 1$ 1. 13, TUG 991-3; Rakvere; coll. by A. Öpik; dorsal view, $\times 1$.

Figs. 14-15. Toxochasmops (Schmidtops) sp. nov. 14, PIU ar 1294; Gräsgård Siltstone; Mälby, Söderon, erratic block No. 1; coll. by C. Wiman, 1901; dorsal view, × 1. 15, RM Ar 55357; Gräsgård Siltstone block, Segerstad, Öland Island, old collection; dorsal view, $\times 1.8$. 
Discussion. Already Schmidt (1881) emphasized the distinction of this species from related forms. The examination of our numerous specimens has revealed a rather perceptible transition from more or less different larger specimens to the morphologically similar but smaller ones. This variability is illustrated here by the specimens figured (compare Pl. III, figs. 1, 2 and figs. 6, 7; Pl. III, fig. 4 and fig. 8). Considering such a great variability, it is difficult to decide whether there are one or two species. For instance, whether the specimens from the Östersjö Limestone erratic boulders of northern Germany, figured by Haller (1973, pl. XIII, figs. 4a,b) as Chasmops wesenbergensis, are really conspecific with wesenbergensis from the Rakvere Stage in northern Estonia or not.

The sole complete specimen of Toxochasmops with the thorax and pygidium has been found by E. Eichwald on Hiiumaa Island, Estonia, as an erratic one. This specimen was figured by Schmidt (1881, pl. IV, fig. 10) as Phacops (Chasmops) wesenbergensis (refigured here, Pl. VI, figs. 2-4). Unfortunately, its cephalon is only an internal mould. Re-examination revealed that this specimen is not wesenbergensis, differing in having (1) a subparabolic, broader cephalon; (2) a narrower, higher, and more convex frontal glabellar lobe; (3) higher cheeks, larger L3, and very small L2; (4) a more convex pygidium. Unfortunately the stratigraphical level (possibly the Nabala Stage) cannot be lithologically established, because the limestone on the reverse side of the specimen is weathered and even its exact locality is unknown. Here this specimen is treated under open nomenclature only as $T$. (Toxochasmops) sp. nov.

$T$. (T.) wesenbergensis differs from all other species of the subgenus in a relatively low glabella, extremely narrow and short preglabellar field, and conspicuously flattened pygidium. The glabellar sculpture (Pl. VI, fig. 1) is most similar to that in $T$. (T.) estonicus from the underlying Oandu Stage.

Occurrence. Rakvere Stage (upper Dicranograptus clingani Zone); Paeküla, Määra, Voore, Vaida, Rakvere, Rägavere, Kaarli, and Piilse exposures; northern Estonia.

Toxochasmops (Toxochasmops) vormsiensis sp. nov.

Plate IV, figures 1-10

1881 Phacops (Chasmops) eichwaldi Schmidt (pars), pl. X, fig. 21.

Derivation of name. After the Vormsi Stage where this species occurs.

Holotype. Partially broken cephalon (TUG 990-14a) from the Vormsi Stage, Kõrgessaare Formation, northwestern Estonia, Vormsi Island, Saxby coast, coll. by the author, 1969; Pl. IV, fig. 1.

Diagnosis. Size large for the subgenus (maximum width of the frontal glabellar lobe $38 \mathrm{~mm}$ ). Frontal glabellar lobe very flat. Anterior margin of cephalon almost horizontal. Anterior part of dorsal furrow gently divergent abaxially. L3 large, 
elongately triangular, moderately flat. L2 pronounced as a rounded knob. Eyes apparently low. Pygidium with high, broad, slanting pleural areas. Foremost pleural rings relatively broad.

Description. The material available includes four incomplete internal moulds of cephalon, eight pygidia, and one fragment of cranidium with preserved sculpture. Cephalon is comparatively flat with deep dorsal furrows. Anterior margin is gently bow-shaped, preglabellar field very narrow in the middle. Width of frontal glabellar lobe equal to the cephalon length. S3 gently sinuous abaxially. Eyes of average size, positioned near dorsal and occipital furrows. Occipital ring lacks anterolateral notches. Surface of glabella covered with disperse small circular tubercles.

Pygidium broadly subparabolic in outline. Rachis relatively broad anteriorly. Interpleural furrows well defined; their distal ends turn obliquely back.

Thorax and hypostoma unknown.

Discussion. The material available is excessively fragmentary for more detailed characterization and comparison of this species. Nevertheless, $T$. (T.) vormsiensis appears to be most similar to $T$. (T.) estonicus sp. nov., in particular with regard to pygidial morphology. All other species are more different.

Occurrence. Vormsi Stage, Kõrgessaare Formation, northwestern Estonia. Exposures on Saxby coast and Kärrslätt on Vormsi Island; Paluküla and Paopea on Hiiumaa Island; Lyckholm, Turvaste, and Mõnuste in the mainland.

Subgenus Toxochasmops (Schmidtops) subgen. nov.

Derivation of name. After Friedrich Schmidt, the author of a comprehensive monograph on Ordovician and Silurian trilobites of Estonia and Ingria.

Type species. Phacops (Chasmops) maxima Schmidt, 1881; from the Keila Stage of northern Estonia and perhaps Ingria.

Other species. Toxochasmops (Schmidtops) proavus sp. nov. from the Jõhvi Substage of the Haljala Stage in northern Estonia; T. (S.) vironiensis sp. nov. from the upper part of the Keila Stage (uppermost Laagri Substage, Saue beds) in northern Estonia (both described below).

Already Schmidt (1881, pl. IV, fig. 3) figured, true enough, probably not real adequately, a cephalon from the Gräsgård Siltstone (?) erratic block from Öland Island as Phacops maxima. However, this specimen belongs rather to a new species of $T$. (Schmidtops). Wiman (1908) assigned a large cephalon and many pygidia collected from the Macrourus Limestone (= Moldå Topoformation) erratic boulders from Uppland, Sweden, also to Chasmops maxima. Re-examination of this incomplete cephalon (PIU ar 1298) revealed that it is similar to $T$. (S.) maximus but should be assigned to a new species of $T$. (Schmidtops) based on the following features: (1) the frontal glabellar lobe is relatively more convex, 
narrower, and descends more steeply to the anterior margin of the cephalon; (2) L3 is broader and shorter; (3) the cephalic margin is less arched in anterior view; (4) the partially preserved granulation on the cheek is slightly coarser.

Another still smaller but more complete cranidium (RM Ar 55357) figured here (Pl. V, fig. 2; Pl. VIII, fig. 15) might be conspecific with $T$. (S.) maximus. A pygidium (P1. VIII, fig. 14), which differs from that of $T$. (S.) maximus in having a narrower pleural portion, may also belong to the new species discussed above. If this assumption is correct, the distribution of the subgenus T. (Schmidtops) is limited to northern Estonia and also to the South Bothnian submarine area.

Diagnosis. Cephalon moderately flat, frontal glabellar lobe relatively broad (maximum width $50 \mathrm{~mm}$ ). Cephalic margin moderately to strongly arched medially in anterior view. Cephalic doublure broad, particularly anteriorly, becoming gently concave in middle (sag.). Genal spines long, with almost vertical outside, and very high in anterior part, becoming lower only in a short distance before the end of spine. Eyes low but relatively long. Surface of palpebral lobe not reaching the level of glabella. Cephalic surface covered by even delicate granulation lacking tubercles. Pygidium long, usually high, with steeply sloping pleural portions. Rachis relatively broad anteriorly. Hypostoma long, with long posterior border.

Discussion. Large specimens of Phacops (Chasmops) from the Jõhvi and Keila stages of northern Estonia were described by Schmidt (1881) as a single species maxima. He mentioned that somewhat different, flatter specimens occur in lower beds (in the Jõhvi Substage of the Haljala Stage by the current stratigraphical classification; Jaanusson, 1995). These specimens are here assigned to T. (S.) proavus sp. nov. which is the earliest known representative of $T$. (Schmidtops). $T$. (S.) maximus, emended here, occurs only in the Keila Stage (from the Ristna beds to the Saue beds) in northern Estonia and possibly in Ingria. The specimens collected from the upper part of the Keila Stage, i.e. from the Saue beds in northeastern Estonia, belong to another new species, $T$. (S.) vironiensis sp. nov. No outcrops of these beds existed in Schmidt's time and the first specimens were collected in the 1930s.

T. (Schmidtops) differs from T. (Toxochasmops) in the following features: (1) the cephalon and proportionately also frontal glabellar lobe are relatively broader; (2) the anterior border of the cephalon is moderately to strongly arched; (3) the palpebral lobe is set lower or at the same level with the glabella; eyes are longer and situated more abaxially; (4) the anterior part of genal spines is noticeably higher; (5) the sculpture of the cephalon consists of very fine and equally spaced granules.

Occurrence. The Jõhvi Substage of the Haljala Stage (upper Diplograptus multidens Zone) and the Keila Stage (lower Dicranograptus clingani Zone) of northern Estonia, the Moldå Topoformation boulders in Uppland and the Gräsgård Siltstone boulders on Öland Island, Sweden, derived from the South Bothnian 
submarine area; these boulders are from the beds equivalent to the Keila Stage and perhaps to the Oandu Stage.

\section{Toxochasmops (Schmidtops) maximus (Schmidt, 1881)}

Plate VII, figures 9-13; Plate VIII, figures 1-3

1881 Phacops (Chasmops) maxima Schmidt (pars), p. 112, pl. IV, figs.1, 2, 6; pl. X, fig. 17; pl. XV, fig. 34; p. 235, fig. 14.

1907 Phacops maxima Schmidt (pars), p. 6, fig. 2.

1925 Chasmops maxima (Schmidt); Bekker, pl. II, fig. 13.

Lectotype. Selected here: nearly complete cephalon (4248/77; Pal. Inst. Russian Acad. of Sciences, Moscow), original of Schmidt, 1881, pl. IV, figs. 1a-c; from the Keila Stage (Pääsküla beds), Keila quarry, northwestern Estonia.

Diagnosis. Largest known species of the subgenus, with broad, notably flat cephalon with steeply declined sides. Cephalic margin anteromedially broadly moderately arched upwards. Genal spines very high anteriorly. Frontal glabellar lobe broader than glabellar length. Eyes long but low, positioned near the centre of the cheeks. Seven to eight backmost pygidial pleural ribs are noticeably narrower than anterior ones, curving strongly backwards.

Description. This species is presumably the largest representative of the whole subfamily (maximum known cephalic width across genal spines $83 \mathrm{~mm}$; TUG 993-352, Pl. VIII, fig. 1). Cephalon relatively flat, nearly semicircular in outline but with steeply declined sides. Genal spines almost vertical, straight, long, and extremely high anteriorly, but still tapering in short distance before the end. Anterior cephalic margin medially broadly moderately arched upwards. Doublure of cephalon broad, weakly convex, turning relatively concave anteromedially. Lateral border furrow well developed. Frontal glabellar lobe comparatively flat, broader than glabellar length. L2 developed as a small knob. S3 strongly sinuous abaxially. Preglabellar furrow well defined medially, preglabellar field conspicuous (sag.). Facial suture runs in front of the preglabellar furrow. Eyes conical, comparatively low, long, and positioned nearly in the centre of the cheeks. Occipital ring and two foremost thoracic rings relatively long (sag.); rings with deep oblique, slightly sinuous interpleural furrow (Pl. VII, fig. 9).

External surface of glabella and pygidium evenly very finely granulate, lacking tubercles. However, the internal mould of the cheek and anterior part of genal spines show small disperse tubercles.

Pygidium subparabolic in outline, almost as long as wide, relatively high anteriorly, becoming gradually narrower backwards. Pleural area strongly convex but descending steeply downwards. Pleural rings relatively broad anteriorly. Seven to eight posterior pleural rings are considerably narrower, curve gradually backwards and become almost parallel to rachis towards the end. Pygidial rachis 
is anteriorly twice as broad as posteriorly and with well-defined ring furrows. Foremost pleural rings show very faint interpleural furrows. Postrachial area even at the end, not elevated. Pygidium in posterior view narrowly triangular in section. Pleural rings become obsolete near the border margin. The exact number of pygidial rings is unknown because no complete pygidia were available. According to Schmidt (1881), pygidia of the composite-species maxima may have 15-18 segments.

Hypostomal median body relatively high and convex, separated from the flat elongate posterior border by a weakly defined middle furrow. Posterior border occupies nearly one-fourth of hypostomal length. Anterior wings are not preserved in the studied specimens. Maculae very narrow and low. Internal mould of median body shows disperse small tubercles.

Occurrence. In the following exposures in northern Estonia: Keila Stage (Dicranograptus clingani Zone), Ristna Substage - Pääsküla; Laagri Substage, Vasalemma Formation - new Vasalemma quarry; Pääsküla beds - Keila, Pääsküla, Kurna, Lilli, Limu, Aruküla; Saue beds - Jälgimägi, Kehra, Rakvere, Tammiku.

Toxochasmops (Schmidtops) proavus sp. nov.

Plate V, figure 1; Plate VII, figures 1-8

1881 Phacops (Chasmops) maxima Schmidt (pars), p. 112, pl. IV, figs. 5, 7; pl. X, fig. 18; pl. XI, fig. 13; pl. XV, fig. 35.

1907 Phacops maxima Schmidt (pars), p. 6.

Derivation of name. Latin proavus, ancestor. Gender masculine.

Holotype. Partially broken cephalon (TUG 990-11) from the Jõhvi Substage of the Haljala Stage, Keila, northeastern quarry; coll. by the author, 1964; Pl. VII, figs. $1-3$.

Diagnosis. A species of average size for the subgenus. Width of frontal glabellar lobe almost equal to glabellar length. Anterior cephalic margin medially gently arched upwards. Dorsal furrows nearly straight. Eyes as long as L3 and positioned near to glabella. Pygidial pleural part low, moderately slanting.

Description and comparison. Only three incompletely preserved cephalons, one with genal spine, were available for examination (Pl. VII, figs. 1-5). This new species is of average size for the subgenus (maximum known cephalic width approximately $64 \mathrm{~mm}$ ). The cheeks are low and gently convex laterally, but not so steeply declined as in maximus. Anterior cephalic margin medially gently arched upwards. Frontal glabellar lobe narrower and more convex laterally than in maximus. Width of the frontal lobe almost equal to glabellar length. L3 proportionally shorter and S3 not so sinuous as in maximus. Dorsal furrows nearly straight and do not turn anterolaterally as in maximus (see Pl. VII, figs. 1, 4). 
Lateral border furrow narrower and weakly defined, genal spines not so high anteriorly as in maximus. Eyes as long as L3, subcircular in outline, and positioned near to L3.

Pygidium broadly triangular in outline. Only some hindmost pleural rings are notably narrower than anterior ones.

Dense, extremely fine, although rarely preserved granulation occurs on cephalon and pygidium ( $\mathrm{Pl}$. V, fig. 1). Hypostoma is similar to that in maximus, but broader and with flatter middle body. Posterior border is also weakly broader and longer (Pl. VII, fig. 7).

Occurrence. Haljala Stage, Jõhvi Substage (Diplograptus multidens Zone), from the following exposures in northern Estonia: Spitham (Põõsaspea), Madise, Karjaküla, Keila (northeastern quarry), Humala, Peetri, Vanamõisa, Alliku, Pääsküla, Kavastu, Aluvere, Kukruse, Soonurme, Jõhvi; Keila Stage, Ristna Substage - Pääsküla exposure. This is the earliest known species of the subgenus appearing in the lowermost beds of the Jõhvi Substage. Besides, in the Jõhvi Substage appear still many other species from the other groups of fauna not known from earlier beds, for instance chasmopine Rollmops, Amplexograptus, and others (Rõõmusoks, 1970). They belong to the Clinambon anomalus-fauna as emphasized by Jaanusson (1945).

\section{Toxochasmops (Schmidtops) vironiensis sp. nov.}

Plate VIII, figures 4-13

1953 Chasmops maxima (Schmidt); Rõõmusoks, pl. I, fig. 9; text-fig. 2 b.

Derivation of name. From the name of the province of Viru (latinized Vironia) in northeastern Estonia, the district where all the material of this species is found.

Holotype. Partially broken cephalon [TUG 990-6 ( $\operatorname{Tr} 1065)$ ] from the Keila Stage, Laagri Substage, Saue beds, Oandu River bank, northeastern Estonia, coll. by the author, 1947; Pl. VIII, figs. 6-8.

Diagnosis. The smallest species of the subgenus (maximum width of cephalon approximately $45 \mathrm{~mm}$ ). Cephalon relatively narrow, in anterior view with laterally steeply sloping narrow cheeks. Glabella is short, transversely evenly and moderately convex, frontal glabellar lobe slightly broader than glabellar length. Anterior cephalic margin strongly arched medially. Pygidium subparabolic in outline, generally conspicuously flat. Postrachial part exceedingly acute-angled in posterior view.

Description. Only two more or less complete cephalons (PI. VIII, figs. 6, 10), in which genal spines are not preserved, were available for examination. Cephalon is almost semicircular in outline, relatively low, and with narrow cheeks. The most characteristic features are strongly anteromedially arched cephalic margin and convex narrow doublure which is abruptly turned upwards. Doublure is weakly 
broader and concave only medially (PI. VIII, figs. 8, 9, 11). Preglabellar field is narrow, ridge-like; preglabellar furrow is medially deep. L3 is narrow, forming half the length of glabella. Dorsal furrows are nearly straight, S3 is a little sinuous distally. Eyes are two times shorter than L3, not positioned near to L3. Posterior branch of the facial suture is situated in a narrow deep furrow (Pl. VIII, fig. 7).

Only incomplete pygidia are available, but they seem to be subparabolic in outline. Pleural areas are low, gently convex, and steepen only in the rearmost part. Rachis is very flat. The posterior pleural rings are broader like in $T$. (S.) proavus, in contrast to these in $T$. (S.) maximus.

External surface of glabella and pygidium bear a very fine even granulation.

An isolated, incomplete hypostoma found from the contemporaneous beds with some glabellae (Pl. VIII, fig. 13) is tentatively assigned to this species. It is remarkably similar to hypostomata of both $T$. (S.) proavus and $T$. (S.) maximus. Unlike in the latter species, the hypostoma in vironiensis shows a broader lateral border, shorter posterior border, lower median body, and narrower anterior wing. External surface of hypostoma is densely and finely granulate, not tuberculate.

Discussion. This species is very similar to the older $T$. (S.) proavus. Both species are of almost the same size and the glabellar morphology is also similar, except for the strongly arched anterior margin and doublure of $T$. (S.) vironiensis. However, the pygidia are noticeably different - in contrast to conspicuously convex pleural areas of proavus, those in vironiensis are rather flat, broader and with lower rachis. T. (S.) maximus differs from vironiensis in having a broader and flatter cephalon and glabella. In maximus the anterior margin is much less arched and eyes are positioned in the centre of the cheeks. As compared to maximus, vironiensis has a longer pygidium with more convex pleural areas.

Occurrence. Keila Stage, uppermost Laagri Substage, Saue beds (Dicranograptus clingani Zone); exposures in the town of Rakvere, Oandu River bank, and Tammiku quarry (all in northeastern Estonia).

\section{ACKNOWLEDGEMENTS}

For the loan of some specimens I am indebted to V. Jaanusson (Naturhistoriska Riksmuseet, Sektionen för paleozoologi, Stockholm) and L. Holmer (Uppsala University). For the opportunity to work at Naturhistoriska Riksmuseet, J. Bergström is gratefully acknowledged. I wish to thank V. Jaanusson for stimulating discussions and suggestions on the manuscript. My work in Sweden in October 1995 was supported by the Estonian Science Foundation. The present study was partly funded by the Estonian Science Foundation, grant 3011. 


\section{REFERENCES}

Angelin, N. P. 1851. Palacontologia Svecica, P. I. Iconographia Crustaceorum Formationis Transitionis. Fasc. I. Lipsiæ (Lundæ).

Antsygin, N. A. 1970. Trilobites of the family Pterygometopidae from the Ordovician deposits of the Urals. In Materialy po Paleontologii Urala (Breivel, M. \& Papulov, G., eds.). Akad. Nauk. SSR, Sverdlovsk, 13-42 (in Russian).

Bekker, H. 1925. Lühike ülevaade Eesti geoloogiast (Eozoiline ja paleozoiline ladekond). Koguteos Eesti. Tartu, 31-61.

Bruton, D. L., Hoel, O. A., Beyene, L. T. \& Ivantsov, A. 1997. Catalogue of the Trilobites Figured in Friedrich Schmidt's "Revision der ostbaltischen silurischen Trilobiten" (1881-1907). Contrib. Palaeontol. Mus. Univ. Oslo, 403.

Dean, W. T. 1961. The Ordovician trilobite faunas of South Shropshire, II. Bull. Brit. Mus. (Nat. Hist.), Geol., 5, 8, 311-358.

Haller, J. 1973. Die ordovizische Trilobitengattung Chasmops aus balto-skandische Geschieben. Paläont. Abh., Abt. A, 4, 723-768.

Harper, A. T. \& Owen, A. W. 1984. The Caradoc brachiopod and trilobite fauna of the upper Kirkerud Group, Hadeland, Norway. Geologica et Palaeontologica, 18, 21-51.

Jaanusson, V. 1945. Über die Stratigraphie der Viru - resp. Chasmops-Serie in Estland. Geol. Fören. Stockh. Förh., 67, 2, 212-224.

Jaanusson, V. 1958. Östersjö (= Baltic) Limestone. In Lexique Stratigraphique International. Vol. I. Europe. Fasc. 2c, Sweden. Paris, 273-274.

Jaanusson, V. 1995. Confacies differentiation and upper Middle Ordovician correlation in the Baltoscandian basin. Proc. Estonian Acad. Sci. Geol., 44, 2, 73-86.

Jaanusson, V. \& Ramsköld, L. 1993. Pterygometopine trilobites from the Ordovician of Baltoscandia. Palaeontology, 36, 4, 743-769.

McNamara, K. J. 1979. Trilobites from the Coniston Limestone Group (Ashgill Series) of the Lake District, England. Palaeontology, 22, 53-92.

McNamara, K. J. 1980a. Taxonomy and distribution of chasmopine trilobites. Geol. Mag., 117, 65-80.

McNamara, K. J. 1980b. Evolutionary trends and their functional significance in chasmopine trilobites. Lethaia, 13, 61-78.

McNamara, K. J. \& Rudkin, D. M. 1984. Techniques of trilobite exuviation. Lethaia, 17, 153-173.

Männil, R. 1966. Evolution of the Baltic Basin During the Ordovician. Valgus, Tallinn (in Russian).

Modlinski, Z. 1973. Stratigraphy and Development of the Ordovician in North-Eastern Poland. Inst. Geol., LXXII.

Owen, A. W. \& Harper, D. A. T. 1982. The Middle Ordovician of the Oslo Region, Norway, 31. The upper Caradoc trilobites and brachiopods from Vestbråten, Ringerike. Norsk. Geol. Tidsskr., 62, 95-120.

Pompecki, J. F. 1890. Die Trilobitenfauna der Ost- und Westpreussischen Diluvialgeschiebe. Beitr. Naturk. Preussens, 7.

Raukas, A. \& Teedumäe, A. (eds.). 1997. Geology and Mineral Resources of Estonia. Estonian Academy Publishers, Tallinn.

Rõõmusoks, A. 1953. Novye dannye o trilobitakh roda Chasmops iz ordovika Estonskoj SSR. Loodusuurijate Seltsi Juubelikoguteos, 1853-1953. Tallinn, 396-413 (in Russian).

Rõõmusoks, A. 1970. Stratigraphy of the Viruan Series (Middle Ordovician) in Northern Estonia I. Valgus, Tallinn (in Russian).

Rõõmusoks, A. 1983. Eesti aluspõhja geoloogia. Valgus, Tallinn.

Rõõmusoks, A. 1986. Oculichasmops - a new genus of the trilobite subfamily Chasmopinae. Proc. Estonian Acad. Sci. Geol., 35, 4, 156-159 (in Russian). 
Rõõmusoks, A. 1997. Ordovician trilobites. In Geology and Mineral Resources of Estonia (Raukas, A. \& Teedumäe, A., eds.). Estonian Academy Publishers, Tallinn, 226-227.

Schmidt, F. 1881. Revision der ostbaltischen silurischen Trilobiten, nebst geognostischer Übersicht des ostbaltischen Silurgebiets. Abt I. Phacopiden, Cheiruriden und Encrinuriden. Mém. Acad. Sci. St.-Pétersb., sér. VII, XXX, 1.

Schmidt, F. 1907. Revision der ostbaltischen silurischen Trilobiten. VI. Mém. Acad. Sci. St.-Pétersb., sér. 8, 20, 8.

Störmer, L. 1940. Early descriptions of Norwegian trilobites. The type specimens of C. Boeck, M. Sars and M. Esmark. Norsk. Geol. Tidsskr., 20, 113-151.

Störmer, L. 1980. Sculpture and microstructure of the exoskeleton in chasmopinid and phacopid trilobites. Palaeontology, 23, 237-271.

Warburg, E. 1925. The Trilobites of the Leptaena Limestone in Dalarne with a Discussion of the Zoological Position and Classification of the Trilobita. Bull. Geol. Inst. Univ. Uppsala, 17.

Wiman, C. 1908. Studien über das Nordbaltische Silurgebiet. II. Bull. Geol. Inst. Univ. Uppsala, 8, 73-168.

\title{
TRILOBIIDID PEREKONNAST TOXOCHASMOPS EESTI ORDOVIITSIUMIS
}

\author{
Arvo RÕ̃̃MUSOKS
}

Perekond Toxochasmops on Põhja-Eestis palju mitmekesisema koosseisuga, kui oli varem teada. Uude alamperekonda $T$. (Schmidtops) kuulub kolm liiki, neist kaks uut, ja alamperekonda $T$. (Toxochasmops) kuus liiki, neist neli uut. Perekonna levik on seotud peamiselt Viru seeriaga ja üks liik Harju seeriaga.

\section{ТРИЛОБИТЫ РОДА ТОХОСНАSМОРS ИЗ ОРДОВИКА ЭСТОНИИ}

\section{Арво РЫЫМУСОКС}

В ордовике Эстонии найдены новые, до сих пор не известные представители рода Toxochasmops. Из нового подрода T. (Schmidtops) описаны три вида (два новых), из подрода $T$. (Toxochasmops) - шесть видов (четыре новых). Виды рода распространены в основном в Вируской серии и только один вид встречен в Харьюской серии. 